\title{
Justice Holmes and the Modernization of Free Speech Jurisprudence: The Human Dimension
}

\author{
G. Edward White†
}

A central puzzle for scholarship on the life and career of Justice Oliver Wendell Holmes has been the tension between his generally deferential theory of judicial review, premised on his acquiescence to majoritarian legislative power, and his role as the founder of modern First Amendment jurisprudence, a source of significant limitation on legislative sovereignty. Professor White reexamines this puzzle in the light of the increased availability of Holmes' private papers, using techniques drawn from biography, intellectual history, and doctrinal analysis. His reexamination of Holmes' free speech decisions casts doubt on a major premise of recent Holmesian commentary-that "positivism," or any ideological encapsulation, is a helpful label for characterizing Holmes' perspective as a jurist. The shift in Holmes' First Amendment jurisprudence is best explained by his personal experiences and relationships, which made him receptive to the ideas of progressive intellectuals as he pursued his interest in disassociating free speech from the jurisprudential underpinnings of "liberty of contract." Holmes' free speech opinions do not conform to a single coherent theoretical pattern because they were not meant to serve as conventional doctrinal formulations that provide guidance for the consistent interpretation of constitutional provisions. Rather, they were meant to serve as vehicles for conveying Holmes' broader philosophical views to the world. In the history of his free speech opinions, he is seen as a resonant intellectual figure, a "lightning rod" for cultural and ideological messages in the first thirty years of the twentieth century. It is in his use of language to this end that the source of Holmes' eminence is to be found.

INTRODUCTION

One of the central puzzles for recent scholarship on the life and career of Justice Oliver Wendell Holmes has been the relationship

$\dagger$ John B. Minor Professor of Law and History and University Professor, University of Virginia. B.A. 1963, Amherst College; M.A. 1964, Ph.D. 1967, Yale University; J.D. 1970, Harvard Law School. My thanks to Mary Anne Case, Gerald Gunther, Michael Klarman, Sanford Levinson, H.L. Pohlman, Robert Post, and David Rabban for their comments on earlier drafts of this Article. 
between the positivistic overtones of Holmes' jurisprudence and his identification with the origins of modern First Amendment theory. The puzzle centers on a conflict between Holmes' generally deferential theory of judicial review, which has been said to be premised on a fatalistic acquiescence to majoritarian legislative power, ${ }^{1}$ and his identification as the modern founder of an approach toward freedom of expression that treats the First Amendment as a source of significant limitations on legislative sovereignty. ${ }^{2}$

For those scholars confronting the apparent tension between Holmes the positivist and Holmes the architect of a speech-protective interpretation of the First Amendment, a particularly significant episode has been a sequence of opinions that Holmes wrote in 1919. The sequence began with Holmes' opinion for the Court in Schenck v. United States, ${ }^{3}$ extended through his opmions for the Court in Frohwerk $v$. United States ${ }^{4}$ and Debs v. United States, ${ }^{5}$ and culminated with his dissent, dehivered about eight months after his Schenck opinion, in Abrams v. United States. ${ }^{6}$ In those opmions Holmes first upheld a series of convictions for subversive advocacy under the Espionage Act of $1917^{7}$ and then dissented froin a decision upholding another conviction under the Sedition Act of $1918^{8}$ for what appeared to be coniparably subversive advocacy. ${ }^{9}$

Commentary on the episode can be divided into two groups. One group of commentators has focused directly on Holmes' opinions in the

1. For example, see Holmes' 1916 statement to Harold Laski: “Man certainly is a personality but the Sovereign kills him when it sees fit and can. . . . I see no meaning in the rights of man except what the crowd will fight for." Letter from Oliver Wendell Holmes to Harold J. Laski (July 28, 1916), in 1 Holmes-LAsk1 Letters: The CoRrespondence of Mr. Justice Holmes and HAROLd J. LASKI 8 (Mark DeWolfe Howe ed., 1953) [hereinafter Holmes-LASKI LETTERs].

2. Perhaps the clearest recent statement of the puzzle is made by H.L. Pohlman, who speaks of "a tension between Holmes's positivism and his defense of the individual right of free speech." H.L. Pohlman, Justice Oliver Wendell Holmes: Free Speech and the Living Constitution 2 (1991). Pohlman seeks to resolve that tension in his study, not successfully in my view, but he deserves credit for recognizing the centrality of the puzzle to an understanding of Holmes' jurisprudence.

3. 249 U.S. 47 (1919).

4. 249 U.S. 204 (1919).

5. 249 U.S. 211 (1919).

6. 250 U.S. $616,624-31$ (1919).

7. Ch. 30,40 Stat. 217.

8. Ch. 75, 40 Stat. 553, repealed by Act of Mar. 3, 1921, ch. 136, 41 Stat. 1359, 1360.

9. One might distingnish between the text of the two statutes and argue that the Sedition Act was more overtly concerned with speech, since it referred to the willful utterance of "disloyal, profane, scurrilous, or abusive language," id., $\S 3,40$ Stat. at 553, while the Espionage Act singled out only the making of "false reports or false statements," tit. $1, \S 3,40$ Stat. at 219 , with the intent to interfere with the operation or success of United States military or naval forces. In all the cases from Schenck through Abrams, however, the defendants communicated opposition to United States participation in World War I through words as well as acts. See infra text accompanying notes 125 27, 142, 249-51. 
sequence and on conteinporary events allegedly affecting his posture in the cases from Schenck through Abrams. ${ }^{10}$ The commentators in this group sharply disagree about the consistency of Holmes' decisions froin Schenck through Abrams and about Holmes' inotivation in reaching the various results. ${ }^{11}$

Another group of commentators has addressed the Schenck-Abrams sequence as part of a larger project, such as the history of late nineteenthand early twentieth-century First Amendinent doctrine or a biographical or analytical overview of Holmes' career. ${ }^{12}$ This group of commentary, inost of which has appeared more recently than the first group, has contributed soine new information and offered soine new perspectives on the sequence. In particular, these commentators have inade use of the increased availability of Holmes' private papers ${ }^{13}$ and have underscored

10. See, e.g., David S. Bogen, The Free Speech Metamorphosis of Mr. Justice Holmes, 11 Hofstra L. REv. 97 (1982) (asserting that the "different tone of the Abrams dissent is not evidence of a marked change in Holmes' view of free speech, but is rather the product of Holmes' frustration at what he considered the misreading by critics and the public of his position in Schenck," id. at 99); Gerald Gunther, Learned Hand and the Origins of Modern First Amendment Doctrine: Some Fragments of History, 27 STAN. L. REV. 719 (1975) (coinparing Holmes' and Learned Hand's First Amendment jurisprudence); Fred D. Ragan, Justice Oliver Wendell Holmes, Jr., Zechariah Chafee, Jr., and the Clear and Present Danger Test for Free Speech. The First Year, 1919, 58 J. AM. HisT. 24 (1971) (examining Holmes' early 1919 free speech opinions); Yosal Rogat \& James M. O'Fallon, Mr. Justice Holmes: A Dissenting Opinion-The Speech Cases, 36 STAN. L. REv. 1349 (1984) (analyzing Holmes' free speech opinions and concluding that Holmes was not uniquely protective of free speech). The last article is consistent with an interpretation of Holmes made much earher by Rogat and as such is part of this earher group of commentaries. See Yosal Rogat, Mr. Justice Holmes: $A$ Dissenting Opinion (pts. 1-2), 15 STAN. L. REv. 3 (1962) [hereinafter Rogat, Dissenting Opinion (pt. 1)], 254 (1963) [hereinafter Rogat, Dissenting Opinion (pt. 2)].

11. For example, compare Gunther, supra note 10, at 724-29 (arguing that Holmes adopted a more speech-protective posture in Abrams in part because of correspondenee and conversations with Learned Hand) with Bogen, supra note 10, at 141-49 (contending that the metamorphosis in Holmes' position came with Schenck and that from that point on Holmes held a speech-protective position). Bogen believes that Holmes' change in position was due principally to his reading the briefs in the first round of the Espionage Act cases. See id. at 146-49.

12. See, eg., Liva Baker, The Justice From Beacon Hill: The Life and Times of Oliver WENDELl Holmes 511-47, 586-89, 621-26 (1991) (account of Holmes' First Amendment opinions, using his private papers); Mark A. Graber, Transforming Free Speech: The AMBiguous LegacY OF CiviL LiBERTARIANiSM 106-12 (1991) (examination of Holmes' free speech opinions and challenge of the view that Holmes was a civil hbertarian); SHELDON Novick, HONORABLE JUSTICE 324-32, 353, 471-74 (1989) (part of biographical account setting forth Holmes' free speeeh opinions); PoHLMaN, supra note 2 (overview of Holmes' free speech opinions as they relate to his constitutional jurisprudence); David M. Rabban, The Emergence of Modern First Amendment Doctrine, 50 U. CHI. L. REv. 1205 (1983) [hereinafter Rabban, Emergence] ("Developinents during the immediate postwar years, rather than spontaneously creating first ainendinent doctrine, rapidly transformed it," id. at 1208.); David M. Rabban, The First Amendment in Its Forgotten Years, 90 YALE L.J. 514 (1981) [hereinafter Rabban, First Amendment] (doctrinal and intellectual history of First Amendment prior to World War I).

13. The Holmes Papers, long in the possession of Harvard Law School with access controlled by authorized biographers, were disseminated to scholars in 1985 in a microfilm edition. Oliver Wendell Holines, Jr., Papers: American Legal Manuscripts from the Harvard Law School Library Microfilm edition, University Publications of America (1985) [hereinafter Holmes Papers]. Future 
the importance of seeing Holmes' First Amendment decisions in the context of changing attitudes toward freedom of expression among late nineteenth- and early twentieth-century American intellectuals. ${ }^{14}$

The contributions of the second group of commentators and the availability of the Holmes Papers have made possible a reexamination of the Schenck-Abrams sequence in the course of a more general reexamination of Holmes' First Amendment jurisprudence. Such a reexamination, based on a combination of techniques drawn from biography, intellectual history, and doctrinal analysis, is the central purpose of this Article. In pursumg that reexamination, I offer some general conclusions about Holmes' stance as a judge.

One of the Article's conclusions is that Holmes' free speech jurisprudence, at one time consistent with positivistic premises, evolved into a posture that cannot easily be reconciled with positivism. ${ }^{15} \mathrm{~A}$ second is that the most fruitful explanations for the change im Holmes' views on free speech lie more im the realm of his personal life and in the intellectual culture of early twentieth-century America than in the realm of "official" doctrinal analysis. The Article suggests that a reexamination of Hohnes' free speech decisions casts doubt on a major premise of recent Holmesian commentary: that "positivism," or any ideological encapsulation, is a helpful label for characterizing Hohnes' perspective as a jurist. ${ }^{16}$

The structure of the Article is as follows. Part II surveys current scholarship on Holmes' free speech jurisprudence. Part III provides an overview of Holmes' early free speech opmions, detailing Holmes' initially orthodox views about free speech. That Part also exannines the changes in commentary on free speech issues and in Holmes' personal life that resulted in his becommg receptive to revising his free speech jurisprudence. Part IV then documents and explains the transformation of Hohnes' stance toward free speech issues. Section IV.A describes

references to the Holmes Papers are to the 1985 Microfilm Edition. In 1983, Harvard Law School, which holds the originals of the Holmes Papers, made them generally available to scholars. Baker and Novick liberally used the Holmes Papers in their biographies. See BAkER, supra note 12; Novick, supra note 12.

14. For evidence of changing attitudes as reflected in cases and commentary between the $1870 \mathrm{~s}$ and the 1920s, see GRABER, supra note 12; Rabban, Emergence, supra note 12; Rabban, First Amendment, supra note 12.

15. On this issue, I openly disagree with Pohlman's conclusion that Holmes' free speech jurisprudence can be reconciled with positivism. See PoHLMAN, supra note 2. My primary interest is not, however, to refute Pohlman, but to approach Holmes' free speech jurisprudence from a vantage point different from that of previous commentators.

16. For a recent influential description of Holmes as a positivist, see Robert W. Gordon, Holmes' Common Law as Legal and Social Science, 10 HofSTRA L. REV. 719 (1982). Gordon's analysis is not directed at Holmes' free speecl opinions, or indeed at any of his opinions as a Supreme Court Justice, but his essay remains one of the more trenchant modern works on Holmes' jurisprudence. 
Holmes' first effort to go beyond the orthodox view he had previously held: a conceptualization of free speech theory as a form of criminalattempt analysis in the 1919 Espionage Act cases, in which the "clear and present danger" test played a deceptive role. Section IV.B sets forth the response of Holmes' younger, "progressive" friends to that effort and their subsequent dialogue with Holmes. Section IV.C discusses the impact of that dialogue, which resulted in the transformation of Holmes' posture in free speech cases from a primarily speech-restrictive to a primarily speech-protective approach. Section IV.D docuinents the completion of that transformation, which resulted in the evolution of Holmes' free speech jurisprudence froin a posture consistent with positivist premises to a posture that cannot easily be reconciled with positivism. Part V concludes that Holmes' perspective on free speech can best be understood as essentially impressiomistic, imtuitive, only deceptively consistent, and not principally directed at the elaboration or clarification of legal doctrine.

II

\section{The Current State of Scholarship on Holmes' First AMENDMENT JURISPRUDENCE}

As previously noted, the evolution of Holmes' theories of free speech has been subject to debate among scholars. ${ }^{17}$ Widespread agreement does exist, however, on several issues. The overwhelming majority of commentators agree that when Holmes began to treat free speech issues seriously after 1918, his approach emerged from his experience with the common-law view of criminal attempts. ${ }^{18}$ Moreover, the overwhelming majority of commentators find Holmes' later Supreme Court decisions more speech protective than his earher ones, although there is disagreement as to whether the successive results he reached are consistent with one another or illustrate a change in Holmes' views. ${ }^{19}$

In addition, commentators have also uncovered a number of cul-

17. For significant works on Holmes' First Amendment opinions, see sources cited supra notes 10-12; see also Harry Kalven, Jr., Professor Ernst Freund and Debs v. United States, 40 U. CHI. L. REv. 235 (1973); Douglas H. Gimsburg, Afterword to Kalven, supra, at 243. Both Ginsburg and Kalven argue that Holmes changed his approach to free speech issues between his majority opinion in Debs and his dissent in Abrams.

18. See, e.g., PohlmaN, supra note 2, at 59-65 (stating that Holmes sometinies imposed liability on nonharmful acts when the speaker's intent was unlawful); Rabban, Emergence, supra note 12, at 1274-78 (stating that Holmes implicitly viewed speeches and articles in Espionage Act cases as attempts). The first commentator to note the relationship between Holmes' early Espionage Act decisions and his views on criminal attempts was Rogat. See Rogat, Dissenting Opinion (pts. 12), supra note 10 .

19. Compare Gunther, supra note 10, at 735-43 (arguing that Holmes changed his opinion on free speech between his opinion in Schenck and his dissent in Abrams) and Rabban, Emergence, supra note 12, at 1305-17 (same) with PoHLMAN, supra note 2, at 53-87 (finding Holmes' free speech opinions consistent) and Bogen, supra note 10 (same). Among the "life and times" biographies, 
tural factors that combined to make the free speech decisions in the latter portion of Holmes' tenure more pressing and significant. First, in part because of the extant jurisprudential orthodoxy on free speech issues, the Supreme Court decided very few free speech cases prior to 1918 , and those few were perceived as comparatively trivial in their impact, dealing with such matters as editorial criticism of public officials and articles on nudity. In contrast, the Supreme Court cases after 1918 arose during legislative efforts to restrict criticism of the conduct of World War I and to suppress collectivist pohtical ideologies that were perceived, in the aftermath of that war, as subversive. The post-1918 cases led to the incarceration of prominent critics of established pohtical orthodoxy and accordingly attracted widespread pubhc attention.

Second, the issue of free speech itself, which prior to World War I had not been a conspicuous feature of reform pohtics, began to galvanize the attention of progressive imtellectuals during and after the war, as progressive journals such as The New Republic took up the cause of free speech. ${ }^{20}$ Earlier arguments conceptualizimg speech as a constitutionally protected "liberty," which had previously been confined to specialist circles, ${ }^{21}$ widened in their reach and were reformulated. At the same time scholarship on the history and theory of the First Amendment began to surface more widely, most conspicuously in Zechariah Chafee's Freedom of Speech, a synthesis of earlier essays that was published in $1920 .^{22}$

Third, several individuals who were particularly interested in free speech issues commumicated their views to Holmes in the years between 1918 and 1920. These mdividuals mcluded Learned Hand, then a federal district judge, Zechariah Chafee, an assistant professor at Harvard Law School, and John Wigniore, the Dean of Northwestern University School of Law, who had been a longtime correspondent of Holmes'. Holmes

BAKER, supra note 12, is aligned with the Gunther/Rabban view, while Nov1ck, supra note 12, is aligned with the Bogen/Pohlman point of view.

20. For the emergence of a consciousness about free speech issues in The New Republic in the years during and after World War I, see David W. Noble, The New Republic and the Idea of Progress, 1914-1920, 38 MISs. VALLEY HIST. REV. 387, 397, 400 (1951).

21. See, eg., Thomas M. Cooley, A Treatise on the Constitutional Limitations Which Rest UPON THE Legislative Power of the STATES OF the AMERICAN UNion (Boston, Little, Brown 1868); ERnst Freund, The Police Power: Public Policy and Constitutional RIGHTS 502-14 (1904) (part entitled "Freedom of Speech and Press"); THEODORE SCHROEDER, FREe SPEech for RAdicals (enlarged ed. 1916); Roscoe Pound, Equitable Relief Against Defamation and Injuries to Personality, 29 HaRv. L. REv. 640 (1916); Henry Schofield, Freedom of the Press in the United States, 9 AM. Soc. Soc'Y: PAPERS \& Proc. 67 (1914). For a discussion of this scholarship, see GRABER, supra note 12, at 17-49; Rabban, First Amendment, supra note 12, at 559-79.

22. Zechariah Chafee, JR., Freedom of SPEech (1920). Chafee's book cites his earlier articles, Zechariah Chafee, Jr., Freedom of Speech in War Time, 32 HARV. L. ReV. 932 (1919) [hereinafter Chafee, Speech in War Time], and Zechariah Chafee, Jr., Freedom of Speech. New REPUBlic, Nov. 16, 1918, at 66 [hereinafter Chafee, Freedom of Speech]. See CHAFeE, supra, at 51 n.21, 57 n.35, 160 n.68, 379,380 . 
also began to discuss free speech issues with his regular correspondents, writing letters to Frederick Pollock and Harold Laski about First Amendment cases that had come before the Supreme Court. ${ }^{23}$

While all of these factors contributed to Holmes' new perspective on free speech in the years immediately following World War I, the precise nature of their combination has hitherto eluded, or at least has not preoccupied, Holmes scholars. At the same time some highly oversimplified views of Holines' First Amendment decisions persist in the literature. ${ }^{24}$ $\mathrm{My}$ interest here is in building on the contributions of commeutators and on archival sources to produce an account of the transformation of Holmes' First Amendment jurisprudence with a different perspective and emphasis. My account is based, in part, upon the sorts of information emphasized by the recent "hfe and times" biographies of Holmes, with particular einphasis on his correspondence in printed and archival sources. My account is also based on an analysis of the changing intellectual history of free speech jurisprudence and on a close reading of the language of Holmes' opinions, emphases that are not present in the recent biographies.

\section{III}

\section{The EArly Cases: Doctrine, Commentary, and CONTEXT}

\section{A. Holmes' Orthodox Free Speech Jurisprudence}

When Holmes left the position of Chief Justice of the Supreme Judicial Court of Massachusetts to sit as Associate Justice of the Supreine Court of the United States in 1902, he had given no indication of holding views on the interpretation of the First or Fourteenth Amendments that singled out speech for special protection against governinental restrictions. Nothing in Holmes' experience on the Supreme Judicial Court of Massachusetts had been consistent with the view that speech inerited special protection. In two unanimous opimions for that Court he had summarily dismissed claims based on free speech, one involving the firing of a police officer for participating in a political campaigu $^{25}$ and the other the punishment of a preacher for speaking on the Boston Common without a permit. $^{26}$ Holmes conceptualized both

23. See, e.g., infra text accompanying notes 171-74, 178 (providing excerpts from Holmes' letters to Laski).

24. See, e.g., Gary J. Aichele, Oliver Wendell Holmes, JR.: Soldier, Scholar, Judge 150-51 (1989) (failing to address how "clear and present danger" test contributed to inconsistency of Holmes' opinions); Novicx, supra note 12, at $474 \mathrm{n} .87$ (attempting to rcconcile Holmes' conflicting free speech opinions by distinguishing speech as action from speech as opinion).

25. McAuliffe v. Mayor of New Bedford, 29 N.E. 517 (Mass. 1892).

26. Commonwealth v. Davis, 39 N.E. 113 (Mass. 1895), aff'd sub nom. Davis v. Massachusetts, 167 U.S. 43 (1897). 
claims as not properly raising free speech issues. Both claims, he said in his opinion in the latter case, rested on "the same kind of fallacy," namely that the state constitution barred a municipality or a state legislature from rescinding the privileges of public employment or speaking in a public park. ${ }^{27}$ For Holmes, there was no constitutional right to "talk politics" in one's capacity as a policeman ${ }^{28}$ or to speak on public property.

Holmes' views on free speecl at that time were not unique. The prevailing orthodoxy when Holmes became a Supreme Court Justice was that the First Amendment was simply a codification of English common law. In the 1897 case of Robertson v. Baldwin, ${ }^{29}$ the Supreme Court noted that the First Amendment, like other provisions of the Bill of Rights, did not institute "any novel principles of governinent," but merely codified "certain guaranties and imınunities which we had inherited froin our Enghish ancestors, and which had from time innnemorial been subject to certain well-recognized exceptions." 30 This meant that First Amendment protection did not extend to libelous, blasphemous, obscene, indecent, or "other publications injurious to public morals or private reputation." 31 Consistent with that view, the Court had upheld the convictions of a Mormon ${ }^{32}$ and an anarchist ${ }^{33}$ for belonging to groups whose views had a tendency to encourage socially injurious acts, sucli as polygainy or the overthrow of governinent, even though neither case presented a clear showing that the defendants had advocated the performance of those acts.

Since, according to this view, the First Ainendment inerely codified the common law, it prevented only prior restraints on speech, such as government censorship of the press, and not subsequent punishment for expressions that had a socially injurious tendency. This had been the position inaintained by William Blackstone in his Commentaries, purporting to summarize Enghish coininon law. ${ }^{34}$ Blackstone had declared that "[t]he liberty of the press ... consists in laying no previous restraints upon publications, and not in freedoin froin censure for criminal matter when published." 35

In his first free speech opinion as a Supreine Court Justice, Holmes adopted Blackstone's view, treating as irrelevant the fact that

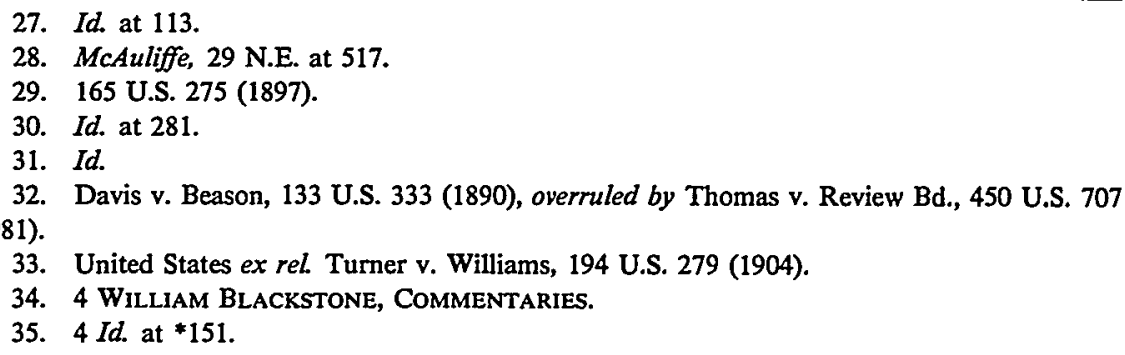


Blackstone's Commentaries did not take into account the text of the Constitution of the United States. The case was Patterson v. Colorado ex rel. Attorney General, ${ }^{36}$ in which an editor had published articles and a cartoon which allegedly "reflected upon the inotives and conduct of the [judges of] the Supreine Court of Colorado in cases still pending." $37 \mathrm{He}$ was convicted of contempt and appealed his conviction on the basis that "[t]o fine or imprison an accused person in contempt proceedimgs for publishing the truth about a judge or court when the truth of the charge is pleaded in justification ... is to deprive him of hberty or property without due process of law."38

The precise constitutional basis of the editor's appeal in Patterson was unclear. He did not argue that the Fourteenth Amendment's Due Process Clause "imcorporated" the First Amendment, but rather that the word "liberty" in the Fourteenth Amendment should be read as including freedom to speak and to write. ${ }^{39}$ Nor did the State of Colorado address the mcorporation issue, argumg only that if there was a liberty to publish true information it should give way to the state's mterest in preserving the orderly administration of justice. ${ }^{40}$ Justice Harlan, however, dissenting in Patterson, argued that the Bill of Rights did apply against the States, relying on the privileges and immunities clause of the Fourteenth Amendment. ${ }^{41}$ Holmes merely said that "it is easier to refer to the Constitution generally for the supposed right [claimed by Patterson] than to poimt to the clause from which it springs." 42 He then left the imcorporation issue open, concluding that "even if we were to assume that freedom of speech and freedom of the press were protected froin abridgeinent on the part not only of the Umited States but also of the States, still we should be far from the conclusion that [Patterson] would have us reach." 43

We will subsequently explore, from another perspective, Holmes' interminglimg of First Amendment "incorporation" arguments and Fourteenth Amendment "hberty of speech" arguments in Patterson. His

36. 205 U.S. 454 (1907).

37. Id. at 459 .

38. Id. at 456 .

39. Id.

40. See id. at 458.

41. Id. at 464 (Harlan, J., dissenting). It was not until 18 years later that a majority of the Court was to hold, without discussion, that the Fourteenth Amendment did incorporate the First Amendment. Gitlow v. New York, 268 U.S. 652 (1925).

In his dissenting opinion in Gitlow, see infra text accompanying notes 359-73, Holmes wrote that " $[t]$ he general principle of free speech, it seems to me, must be taken to be included in the Fourteenth Amendment, in view of the scope that has been given to the word 'liberty' as there used." Gitlow, 268 U.S. at 672 . For a discussion of the implications of that language, see infra text accompanying notes $362-64$.

42. Patterson, 205 U.S. at 461-62.

43. Id. at 462 . 
grouping together of those arguments, however, also signaled that he did not think either the First or Fourteenth Amendments had a significant effect on the power of the state to restrict speech. "In the first place," he argned, citing decisions following Blackstone, "the main purpose of such constitutional provisions is 'to prevent all such previous restraints upon publications as had been practiced by other governments,' and they do not prevent the subsequent punishment of such as may be deemed contrary to the public welfare."44 Holmes thus reduced the constitutional issues in Patterson to whether Colorado's puinshment of the editor was a reasonable exercise of its police powers. That question answered itself. The editor had criticized the motives of state judges in cases pending before them. The "propriety and necessity of preventing interference with the course of justice by premature statement, argument, or intimidation," Holmes declared, "hardly can be denied."45 In the vocabulary of the time, Patterson was a simple "police power" case in which a "bad tendency" of a commumication had been identified: the standard of judicial scrutiny was mimimal.

But the editor in Patterson had not merely claimed a right to comment about public trials and the judges who decided them; he had claimed that his statements about the corrupt and partisan motives of Colorado judges were true, and he had offered to prove their truth. ${ }^{46}$ That fact did not matter to Holmes. At common law, he noted, "[ $t]$ he preliminary freedom extends as well to the false as to the true; the subsequent puinshment inay extend as well to the true as to the false. This was the law of criminal libel apart from statute in most cases, if not in all."47 In other words, the State of Colorado could decide that it did not promote the public welfare even for persons to make true statements about the conduct or motives of judges: it could treat those statements as crimmal libels. If the statements had a tendency to interfere with the administration of the law, they could be suppressed without regard to their trutli or falsity.

The combination of the prior-restraints limitation on First Amendment claims with the bad-tendency test employed as an evaluative standard for pohce-power himitations on free speech made Holmes' Patterson opmion very restrictive. Under its reasoning a state could suppress even true speech if it concluded that the words had a tendency to proinote socially injurious acts. If a newspaper said that a particular decision of the governor of the state, or one of its courts, was reactionary and contrary to the public welfare, then that comment could apparently,

\footnotetext{
44. Id.

45. Id. at 463 .

46. Id. at 461 .

47. Id. at 462 .
} 
after Patterson, be made the basis for a contempt conviction simply because it might tend to undermine respect for elected officials or tend to interfere with the administration of justice.

Eight years after Patterson Holmes again advanced a restrictive theory of freedom of speech in a Supreme Court case, once more sanctioning the use of "bad tendencies" as a justification for subsequent pumshment of speech. The case was Fox $v$. Washington, ${ }^{48}$ in which he spoke for a unanimous Court. The petitioner in Fox was an editor whose magazme had published an article, The Nude and the Prudes, discussing the infiltration of a group whose members occasionally practiced nude bathing. ${ }^{49}$ The group was infiltrated by "a few prudes," who "proceeded in the brutal, uuneighborly way of the outside world to suppress the people's freedom," and ultimately had four members of the group arrested for indecent exposure. ${ }^{50}$ The article called for a boycott of the "prudes" " busmesses, declaring that " " $t \mathrm{t}]$ he boycott will be pushed until these invaders will come to see the brutal mistake of their action and so inform the people." "51

The state of Washington prosecuted the editor of the article under a state statute making it a gross misdemeanor to willfully pubhish, edit, or circulate any written matter " which shall tend to encourage or advocate disrespect for law or for any court or courts of justice." "52 A jury convicted the editor and, on appeal, the Washington Supreme Court held that his article was "not a criticism of the law, but was calculated to, and did, incite the violation of law."53 It noted that the right of free speech did not mean "that persons may with impumty advocate disregard of law."54 The editor attacked the statute primarily on the ground that its controllimg standard, "disrespect for law," was too vague, since " "who can say what language will produce that state of mind?" "55 The editor also claimed that the statute deprived him of his liberty under the Fourteenth Amendinent and that the Court in Patterson had left open the question whether the First Amendinent could be applied to the states. ${ }^{56}$

Holmes, in sustaining the conviction, said that "[w]e understand the state court by implication at least to have read the statute as confined to

\footnotetext{
48. 236 U.S. 273 (1915).

49. Id. at 276.

50. Id.

51. Id. at 276-77.

52. Id. at 275-76 (quoting Wash. Remington \& Ballinger's CODE $§$ 2564).

53. State v. Fox, 127 P. 1111, 1112 (Wash. 1912), aff'd sub nom. Fox v. Washington, 236 U.S.

54. Id. at 1112.

55. Rabban, First Amendment, supra note 12, at 535 (quoting Brief for Plaintiff-in-Error at 15, Fox v. Washington, 236 U.S. 273 (1915) (No. 134, 1914 Term)).

56. Id. at 535 n.91; see also Fox, 236 U.S. at 274.
} 273 (1915). 
encouraging an actual breach of law," and "[i]t does not appear and is not likely that the statute will be construed to prevent publications merely because they tend to produce unfavorable opinions of a particular statute or of law in general." $57 \mathrm{He}$ asserted that in this case "the disrespect for law that was encouraged was disregard of it-an overt breach and technically criminal act." $\$ 58$

There was no evidence, however, that the Washington courts would construe the statute so as to limit its application to actual breaches. Indeed, the facts of Fox suggested that the Washington courts would reach out to apply the statute to publications that "tend[ed] to produce unfavorable opinions." The article in Fox was such a publication. In sentences such as the one referring to "the privilege to bathe in evening dress, or with merely the clothes nature gave thein," 59 the article tended to communicate the "unfavorable" opinion that nudity in public was an appropriate activity. It appeared that the "disrespect for law" shown in the article was not the advocacy of a boycott, but rather the championing of public nudity.

Holmes further stated that "by indirection but uninistakably the article encourage[d] and imcite[d] a persistence in what we must assume would be a breach of the state laws against indecent exposure." ${ }^{\circ 0} \mathrm{He}$ thus interpreted "disrespect" in the Washington statute as "nianifested disrespect, as active disregard [for the] law."61 As a result, the statute fell into a class of laws that proscribed "encouragennents that, . . . if directed to a particular person's conduct, generally would inake him who uttered thein guilty of a misdemeanor" at common law. ${ }^{62}$ "Laws of this description," Holmes concluded, "are not unfaniliar."63

Fox thus illustrated another Supreme Court application of the badtendency test to speech-restrictive legislation, a test that permitted states to suppress speech that had a "tendency" to incite or encourage socially undesirable acts. In Fox the Court applied the test quite broadly, since the speaker had not encouraged others to engage in public nudity but rather to boycott the businesses of those who had taken a "prudish" stance toward it. This suggested that any negative characterizations of persons who criticized others for purportedly engaging in an activity that a state had forbidden-such as working on Sunday or dropping out of school at the age of twelve- had "bad tendencies" and could be made the basis of criminal prosecutions.

57. Fox, 236 U.S. at 277.

58. Id.

59. Id. at 276 .

60. Id. at 277.

61. Id.

62. Id.

63. Id. at 278 . 
Taken together, Patterson and Fox apparently left very hittle room for the First or Fourteenth Amendments to serve as a restraint on state legislation restricting efforts to criticize public officials or to protest majoritarian views. The decisions were consistent with judicial orthodoxy im free speech cases prior to the United States' involvement im World War I. They were not consistent with a later characterization of Holmes as having "a solicitude for individual expression." 64

\section{B. Commentary on Free Speech Issues in the Late Nineteenth and Early Twentieth Centuries}

The orthodox positions Holmes adopted in his early free speech cases do not represent a complete picture of the state of pre-World War I free speech jurisprudence. Recent scholarship has brought to hight a quite different tradition of attitudes towards free speech that surfaced from the 1870s through World War I.65

This alternative free speech jurisprudence attracted commentators of sharply diverging ideological perspectives. Some were early twentiethcentury political reformers who sought to expand the opportunities for critics of established governmental and societal practices to be heard. ${ }^{66}$ A greater number of the commentators, however, were closer to Holmes im age, and can be identified with an established late nineteenth-century "liberal" ideology that emphasized the lack of legitimate power in the state to intrude imto a private citizen's affairs. ${ }^{67}$

The most significant feature of this alternative tradition of comnientary, for present purposes, is its implications for free speech cases in the period during and after World War I. To understand those implications it is necessary to understand the philosophical premises upon which the commentary was based. A central premise driving the commentary in its nineteenth-century versions was that the concept of liberty subsumed a cluster of fundamental values, including individual autonomy in matters of tastes and preferences, freedom of exchange in the marketplace, and the fruits of property ownership. Liberty was thus a concept of great inportance and potentially broad scope, whose promotion furnished one of the rationales for government itself. The assumed fundaniental status of liberty in American culture was the base point from which arguments supporting the judicial doctrine of "liberty of contract" in late nine-

64. The Mind and Faith of Justice Holmes: His Speeches, EsSays, Letters and JUDICIAL OPINIONS 289 (Max Lerner ed., 1943).

65. See GRABER, supra note 12, at 17-65; Rabban, First Amendment, supra note 12, at 559-79.

66. Examples were Theodore Schroeder, Ernst Freund, and Henry Schofield. See GrabER, supra note 12, at 54-65; Rabban, First Amendment, supra note 12, at 560-75.

67. Some of the commentators were Thomas M. Cooley, Christopher G. Tiedeman, John W. Burgess, and John B. Minor. See Graber, supra note 12, at 17-44; Rabban, First Amendment, supra note 12 , at $560,563-64$. 
teenth- and early twentieth-century substantive due process cases were derived. Those same arguments were potentially applicable to cases raising Fourteenth Amendment objections to governmental restrictions on speecli, and were advanced by several treatise writers and commentators in the late nineteenth century. ${ }^{68}$ In summary, the arguments demanded that the same presumptions agamst governmental interference with individual liberty that ought to be invoked in cases involving governmental efforts to regulate economic relationships also be applied to governinental efforts to regulate speech. ${ }^{69}$ Botli sets of cases raised the specter of potential threats to hiberty.

While "hiberty of contract" was a commonly invoked judicial concept in late nineteenth- and early twentieth-century case law, an analogous treatment of "hberty of speech" rarely appeared. There were two principal reasons for the hidden status of the "liberty of speecli" argument. First, as noted earhier, tliere were no federal and only a handful of state statutes that directly regulated speech during the time of the 1917 Espionage $\mathrm{Act}^{70}$ and the 1918 Sedition Act, ${ }^{71}$ and thus very few Supreme Court cases involved the issue of governmental power to restrict speech. ${ }^{72}$

Second, while the status of "liberty of speech" was theoretically independent of the status of other liberties, late nineteenth-century legal doctrine tended to subsume issues of "speech" in issues conceived as involving econounic liberty. In two late nineteentli-century Supreme Court cases, for example, the "free speecli" issues were treated by botli sides as derivative of economic issues. In tlie first case, In re Debs, ${ }^{73}$ a federal court order enjoming Eugene Debs and others fron1 encouraging railroad workers to leave their jobs was treated as an alleged infringenent of a constitutional right to engage in the labor practice of a strike. ${ }^{74}$

68. See, eg., John W. Burgess, Political Science and Comparative Constitutional LAW (1913 prtg.) (1890); Cooley, supra note 21; Christopher G. Tiedeman, A Treatise on The Limitations OF Police Power in THE UNIted States (St. Louis, F.H. Thomas 1886). See generally GRABER, supra note 12, at 18-21 (discussing the philosophical foundations of civil libertarianisin).

69. See GraBer, supra note 12 , at 18-24.

70. Espionage Act of 1917, ch. 30, 40 Stat. 217.

71. Sedition Act of 1918, ch. 75, 40 Stat. 553, repealed by Act of Mar. 3, 1921, ch. 136, 41 Stat. $1359,1360$.

72. See Paul L. Murphy, The Meaning of Freedom of Speech: First Amendment FREedoMS FROM WILSON TO FDR 16-17 (1972) [hereinafter MURPHY, FREEDOM OF SPEECH] (arguing that formal repression was unnecessary because communication between people of different economic and social-class status was infrequent); PAUL L. MURPHY, WORLD WAR I AND THE ORIGIN OF CIVIL LIBERTIES IN THE UNITED STATES 51 (1979) (discussing reasons why government did not need to suppress free speech before World War I); Rabban, First Amendment, supra note 12, at 519 (noting that the period following World War I was characterized by a marked increase in First Ainendment prosecutions, judicial discussions, and scholarly commentary).

73. 158 U.S. 564 (1895).

74. Id. at 574-75. 
In the second case, Davis v. Massachusetts, ${ }^{75}$ in which the Supreme Court affirmed the position taken below by Holmes in Commonwealth $v$. Davis, ${ }^{76}$ the issue of a person's right to speak on the Boston Common was treated as derivative of the powers of municipal corporations to restrict activities of any kind on city property. ${ }^{77}$

The existence of a jurisprudential tradition grounding free speech protection on a broad interpretation of the concept of hberty was thus largely confined to scholarly hiterature prior to World War I. Moreover, that tradition differed from the orthodox view of free speech only in some respects. Those who conceptualized free speech as a hiberty under the Fourteenth Amendment did not beheve that the constitutional provisions on free speech merely codified the common law and therefore confined free speech protection to freedoin froin prior restramts. ${ }^{78}$ It did not follow, however, that those individuals believed that free speech was to be given absolute or even extensive protection. On the contrary, inany assumed that the liberty to speak could be balanced against the power of a government to defend itself in war or against attacks that threatened its own existence. ${ }^{79}$

It is not clear, then, that the Patterson or Fox cases would have been decided differently had the late nineteenth-century view of speech as a liberty challenged Holmes' early orthodox view. ${ }^{80}$ What is clear, however, is that when pohitical reformers began to devote greater attention to the question of expanding protections for political dissidents in tlie early twentieth century, an earlier tradition of commentary treating speech as a fundamental hiberty was available to them. Along with that tradition, however, came part of its intellectual baggage: the identification of hiberty with doctrimes, such as "hiberty of contract," that by the early twentieth century had troublesome political implications. ${ }^{81}$

75. 167 U.S. 43 (1897).

76. 39 N.E. 113 (Mass. 1895), aff'd sub nom. Davis v. Massachusetts, 167 U.S. 43 (1897).

77. Davis, 167 U.S. at 46-48; see also Rabban, First Amendment, supra note 12, at 529-30 (discussing Court's failure to address First Amendment claims im Davis).

78. Cooley and Tiedeman directly challenged that view. See Cooley, supra note 21, at 421; TIEDEMAN, supra note 68 , at $191-92$.

79. See CoOley, supra note 21, at 428; TIEDEMAN, supra note 68, at 192; see also ThOMAS M. Cooley, The General Principles of Constitutional Law in the United States of AMERICA 277-78 (Boston, Little, Brown 1880) (government could intervene to suppress speech threatening "the abolition of republican institutions").

80. The defendants in Patterson and Fox arguably threatened the existence of "republican institutions" by encouraging disrespect for the law or its officials. See supra text accompanyiug notes 36-63.

81. The "liberty of contract" doctrine was criticized during the first decade of the twentieth century for being unresponsive to changing social and economic conditions. See, e.g., Roscoe Pound, Liberty of Contract, 18 YALE L.J. 454, 464 (1909). See generally G. EdWARd WhiTE, From Sociological Jurisprudence to Realism: Jurisprudence and Social Change in Early Twentieth-Century America, in PATterns of AMERICAN Legal. ThOught 99, 102-07 (1978) (discussing the displacement of "mechanical jurisprudence" by sociological jurisprudence). 
The potential use of liberty arguments as a source of protection for the controversial expressions of political dissidents, such as anarchists, labor organizers, and advocates of unconventional and arguably "obscene" sexual practices, caused a dilemma for early twentietli-century reformers mclined to cliallenge orthodox free speech jurisprudence. While they were prepared to resist judicial efforts to confine protection for speech to prior restramts, to permit suppression of expressions that had "bad tendencies," or to ignore free speech issues altogether, to do so on the basis of a broad-ranging conception of liberty would implicitly require them to acknowledge the primiacy of that conception in the arena of economic affairs. In short, the liberty premise of protection for free speech seemed to legitimate other protections-such as freedom of contract-to which early twentieth-century pohtical reformers were distinctly unsympathetic.

Over the first two decades of the twentieth century, political reformers who were supporters of free speecli exhibited two different responses to the potential ramifications of the argument premised on liberty. One response was to disassociate freedom of contract from the general realm of protected liberties, eitlier on the ground that liberty involved material possessions, which were necessarily secondary to the more fundamental right of human existence, ${ }^{82}$ or on the ground that the liberty being protected was a fiction given the unequal bargaining status of many contractimg employers and employees. ${ }^{83}$

The otlier response had far greater ramifications for the development of modern First Amendment theory. It constituted a reorientation of the premises underlying a speech-protective interpretation of the constitutional provisions affectimg freedom of expression. That reorientation took place in two discernible stages. In the first stage, a group of "progressive" 84 political reformers confronted the implications of the liberty premise for numerous proposed legislative reforms and concluded that when the values associated with social progress conflicted with those associated with individual liberty, the latter set of values slould give way to the former. ${ }^{85}$ In the second stage, in part as a response to the implications of this conclusion, the liberty premise of free speech protection was reframed as a democracy premise. Thus the locus of philosophical

82. See, e.g., SCHROEDER, supra note 21 , at 13, 94.

83. See, e.g., FREUND, supra note 21 , at 539.

84. The term "progressive" is placed in quotes to signify that it was a label these reformers attached to themselves. Many were identified with the progressive movement in American politics that emerged as an influential political force in the early years of the twentieth century. See WHrTE, supra note 81 , at 103-04.

85. See GRABER, supra note 12, at 75-86 (chapter entitled "Progressive Responses to Free Speech Conflict, 1915-1927"). Graber discusses the assertion of many progressives that "preserving social community under modern conditions required an individual conformity inconsistent with broad rights of political dissent." Id. at 76. 
energy animating solicitude for free speecli was shifted from the imdividual as an autonomous being to the individual as a participant in a democratic society. The sources of protection for free speecl became identified not witl the interest of the individual whose liberty government existed to further, but with the social interest in furthering democratic principles by encouraging independent public discussion and debate. ${ }^{86}$

Holmes was to emerge as one of the founders of modern First Amendinent theory at the same moment in time when this second stage im the reorientation of the premises of free speech jurisprudence was taking place. I will subsequently discuss the relationship between Holmes and progressive imtellectuals who were engaged in the reorientation process. At this point, as a prelude to that discussion, I want to take up another element im the context of Holmes' early free speecli cases: his perception of the way others were reacting to his work on the Court im the first decade of his tenure as a Justice.

\section{The Personal Context of Holmes' Early Decisions: A Quest for Recognition}

During the same time period that Holmes was adhering to his orthodox view of free speech and commentators were seeking to articulate alternative views, Holmes was undergoing a series of changes in his personal life. These changes, which centered on the nature and significance of his friendships, were to provide an additional catalyst for the transformation of lis free speech jurisprudence.

Prior to becoming a Supreme Court Justice in 1902, at the age of 61, Holınes' social and intellectual life had a distinctive, and seemingly contradictory, tenor. Following a pattern he had initiated very early in his professional career, Holmes did not participate extensively in social affairs in Boston, where he had lived his entire life. He absorbed hiınself in his judicial work and im mtellectual pursuits, such as extensive reading and frequent letter writing, during his leisure time; he and his wife rarely entertamed or socialized. ${ }^{87}$ At the saine time, however, Holmes devel-

86. The idea of free speech being related to social interests had been mentioned by Roscoe Pound and Henry Schofield. See Roscoe Pound, Interests of Personality (pt. 2), 28 HARV. L. REv. 445,453 (1915) (discussing social interest in individual free speech); Schofield, supra note 21, at 9192 (asserting that the "common right of public and truthful discussion of public affairs exists as a right held in trust for the educational profit and benefit of the public," id. at 91). This relationship was to become central to the views of Zechariah Chafee, Jr., the most significant figure in the reorientation of modern free speech jurisprudence. See infra text accompanying note 211; see also GRABER, supra note 12, at 122-51 (noting that Chafee has been regarded as the most influential legal scholar in the area of civil liberties); Rabban, First Amendment, supra note 12, at 563-64, 587-89 (commenting that prewar scholars, including Chafee, provided the theoretical underpinnings for modern First Amendment doctrine).

87. On Holmes' social contacts in his years in Boston, see G. Edward White, Holmes's 'Life 
oped a series of "flirtatious" 88 relationships with women in Boston, and especially in England, to which he frequently traveled in the summers after $1887 .{ }^{89}$

After he became a Supreine Court Justice, however, Holmes changed his patterns of socializing. He and his wife, Fanny Dixwell, briefly became active participants in Washington political society, entertaining and dining out frequently. ${ }^{90}$ At the same time Holmes informed his female correspondents that he would no longer be playing the roles of courtier and "flirt" in Washington, partly because of the provincial gossip of that city and partly because of the absorbing nature of his new work. ${ }^{91}$ After restricting his informal social contacts, Holmes turned more and nore to his role as a correspondent and to the friendships associated with that role. ${ }^{92}$ Eventually, by the onset of the First World War, he ceased travehing to England altogether. ${ }^{93}$

During these early years of Holmes' tenure on the Supreme Court, a central theine in his life was the juxtaposition of his great interest in his work with his frustration with the lack of appreciation of his contributions. In his correspondence during the period from late 1902, when he first noted his reactions to his new position, to 1912, when his friendship

Plan": Confronting Ambition, Passion, and Powerlessness, 65 N.Y.U. L. REv. 1409, 1436-39 (1990) [hereinafter White, Life Plan]. On his reading and letter writing, see G. Edward White, Holmes As Correspondent, 43 VAND. L. REv. 1707, 1749.61 (1990) [hereinafter White, Correspondent].

88. The term "flirtatious" has been placed in quotes to emphasize that it was an adjective commonly applied to his extramarital friendships by contemporaries. See, e.g., Alice James, Journal entry (June 16, 1889), in Alice JAMEs: Her BRothers-Her Journal 93 (Anna R. Burr ed., 1934) [hereinafter ALICE JAMES: HER JOURNAL] (describing Holmes as having "certainly broken loose and ... flirting as desperately as ever"); Letter from Harold J. Laski to Oliver Wendell Holmes (July 29, 1924), in 1 HOLMES-LASKI LETTERS, supra note 1, at 640 (informing Holmes that a woman "remembered you most perfectly in the 'nineties as the most perfect flirt in London"). Alice James was the sister of William and Henry James, close acquaintances of Holmes in Boston in the 1860s. See Alice JAmes: Her Journal, supra, at 6; see also 1 MARK DeWolfe Howe, Justice OLIVER WeNDELl Holmes: The SHAPING YeARS 1841-1870, at 201 (1957).

89. See White, Correspondent, supra note 87, at 1714, 1727-31; White, Life Plan, supra note 87, at 1439-42. These relationships had culminated in an emotional attachment to Clare Castletown, the wife of Bernard Fitzpatrick Castletown, a titled Anglo-Irish member of Parliament. White, Correspondent, supra note 87, at 1732. Holmes first met Clare Castletown in London in 1889 , sent her a copy of the first edition of his volume of extrajudicial address, Speeches, when it was published in 1891, and on returning to England in 1896 renewed acquaintances with her. Id. at 1733. Between 1896 and the 1920s (Clare died in 1927) he wrote her over 100 letters that have survived; only a few of hers to him have survived. Id. at 1735 . The letters were first published by John S. Monagan as The Love Letters of Justice Holmes, Boston GLOBE MAG., Mar. 24, 1985, at 14. For more detail on the relationship between Holmes and Clare Castletown, see White, Life Plan, supra note 87, at 1442-57; White, Correspondent, supra note 87, at 1731-44.

90. See White, Life Plan, supra note 87 , at 1461-66 and sources cited therein.

91. See id.

92. See White, Correspondent, supra note 87, at 1709-10; see also White, Life Plan, supra note 87, at 1463-64 and sources cited therein (especially noting his lack of personal contacts with women in Washington).

93. White, Correspondent, supra note 87, at 1709. 
with Felix Frankfurter first began to blossom, there are numerous letters describing his delight with the work of a Justice, especially its national dimensions and its intellectual depth and variety. ${ }^{94}$ There are also several letters confessing his exalted ambitions as a jurist, his feeling of being apart, in his concerns and his intellectual mclinations, from his colleagues on the Court, and especially his sense that his reputation, even anong the cognoscenti, was not commensurate with his talents and contributions. ${ }^{95}$ This last reaction of Holines' cannot easily be dismissed as false modesty or evidence of an insatiable drive for success. While both of those characteristics can fairly be attributed to Holmes, ${ }^{96}$ there is independent evidence that he was not particularly well known, let alone widely admired, during his first decade on the Court. ${ }^{97}$

The changes in Holmes' life that were ushered in by the theines of his early years on the Court precipitated a change in the nature of his friendships. In place of his friendships with women, and also as a surrogate for the loss of some of his older male friends, such as Chief Justice Melville Fuller and Jolın Chipman Gray, ${ }^{98}$ Holmes substituted a new set of friendships with a group of young intellectuals who had coine to notice and to appreciate his work as a scholar and a judge. ${ }^{99}$ The central figure in this group of Holmes acolytes was Felix Frankfurter, who first befriended Holmes in 1912, when Frankfurter was 29 and Holmes 71. ${ }^{100}$ Through Frankfurter, Holines cane into contact with a number of Frankfurter's conteinporaries, such as Harold Laski, Walter Lippmann,

94. See White, Life Plan, supra note 87 , at 1461-62 and sources cited therein.

95. See id. at 1462 and sources cited therein.

96. See Yosal Rogat, The Judge as Spectator, 31 U. CHI. L. REV. 213, 227, 233-34, 253-54

(1964). On Holmes' drive for recognition and success, see 1 HowE, supra note 88, at 281-84; 2 Mark DeWolfe Howe, Justice Oliver Wendell Holmes: The Proving Years 1870-1882 (1963); White, Life Plan, supra note 87, at $1457-60$ and sources cited therein.

97. For example, Alexander Bickel and Benno Schmidt make the following analysis: Nearly thirty years after publication of The Common Law and after his first judicial appointment, the public hardly knew [Holmes]. . . . In professional circles, to be sure, and among his colleagues, there was recognition, to a degree, of Holmes' stature. . . .

Yet in his seventieth year, even among his professional peers, the general acknowledgment of greatness was still to come for Holmes, and he himself felt its absence rather painfully. He was, then as now, often charged with obscurity and with a disinclination to take particular facts into account . . . .

9 AleXander M. Bickel \& BenNo C. SChmidr, JR., The Judiciary and Responsible GOVERNMENT 1910-21, at 69-70 (1984). Bickel cites a 1912 exchange between William Howard Taft, then President of the United States, John Chipman Gray, Holmes' intimate friend who was then on the Harvard Law faculty, and Taft's son Robert Taft, a Harvard student who had been offered the position of seeretary for Holmes for the 1913-14 Term. The parties acknowledged that, as Gray put it, " 'Judge Holmes' opinions seem sometimes to lack lucidity." "Id. at 70. President Taft ultimately concluded that his son would learn hittle from Holmes that he had not alrcady learned at Harvard. Id.

98. Both had died by 1915.

99. White, Life Plan, supra note 87 , at $1467-72$ and sources cited therein.

100. On the origins of the Holmes-Frankfurter friendship, see BAKER, supra note 12, at 454-55; White, Life Plan, supra note 87 , at $1467-69$ and sources cited therein. 
Herbert Croly, Learned Hand, Morris Cohen, and Zechariah Chafee. ${ }^{101}$ Outside of this circle, Holmes also made other friends who were roughly the same age as Frankfurter, such as the British diplomat Lewis Einstem. ${ }^{102}$

Three distinguishing features of Frankfurter and his contemporaries intrigued Holmes. First, they were distmctly inen of the twentieth century, "moderns," "progressives," rehigious skeptics, and relative enthusiasts for democracy, pluralism, and beneficent affirmative government. As such they seemed to Holmes to be men of the future. Second, they were enthusiastic, even fawning supporters of Holmes as a jurist, and thus gave Holmes the attention and praise he coveted. ${ }^{103}$ Third, and perhaps most importantly, Frankfurter and his contemporaries provided Holmes with a rationale for doing something he very much wanted to do: to continue in active service as a Supreme Court Justice well past the point where he was ehgible to retire on a full pension. ${ }^{104}$

Before meeting Frankfurter and his circle, Holmes had written to friends that he was contemplating retirement when he became eligible to do so on a full pension; after coming to know his younger acquaintances and encountering their praise, he wrote that he saw no reason to leave the Court while he felt he could do the work. ${ }^{105}$ Doing the work, however, now had a different dimension for him: it was not simply "[getting] to the bottom"106 of cases, nor writing his opinions "with style,"107 but cominumicating to a younger generation of admirers and potential disciples. By the onset of World War I the jurisprudential context of Holmes' First Amendment opinions was beginning to change, as was his conception of the audience for, and im that sense the "meaning" of, those opinions.

The transforination of Holmes' free speech jurisprudence, then, was

101. White, Correspondent, supra note 87, at 1709; White, Life Plan, supra note 87, at 1470.

102. Holmes first met Einstein through his friendship with Bernard and Clare Castletown. See Lewis Einstein, Introduction to THE Holmes-EINSTEIN LeTTERS: CoRrespondeNCE of Mr. JUSTICE Holmes AND Lewis EINSTEIN 1903-1935, at xx (James B. Peabody ed., 1964).

103. See White, Life Plan, supra note 87 , at 1471.

104. See id.

105. On Holmes' seeing no reason to leave the Court, see Letter from Oliver Wendell Holines to Sir Frederick Pollock (Dec. 15, 1912), in 1 Holmes-Pollock LetTERs: The CoRrespondence OF Mr. Justice Holmes AND Sir Frederick Pollock 1874-1932, at 204, 205 (Mark DeWolfe Howe ed., 1941) [hereinafter HolmEs-Pollock LETTERS]. For examples of praise from younger acquaintances, see Letter from Felix Frankfurter to Oliver Wendell Holmes (Mar. 7, 1912), in Holmes Papers, supra note 13; Letter from Felix Frankfurter to Oliver Wendell Holmes (Feb. 19, 1912), in Holmes Papers, supra note 13; Letter from Felix Frankfurter to Oliver Wendell Holmes (Feb. 10, 1912), in Holmes Papers, supra note 13.

106. Oliver Wendell Holmes, Speech to the Bar Association of Boston (Mar. 7, 1900), in THE Occasional Speeches of Justice Oliver Wendell Holmes 122, 123 (Mark DeWolfc Howe ed., 1962).

107. Letter froun Oliver Wendell Holmes to Canon Patrick A. Sheehan (Dec. 15, 1912), in Holmes-SheehaN CoRRespondence 55, 56 (David H. Burton ed., 1976). 
part of a larger process by which he sought to embrace a new set of friends and constituents. The course of that transformation, however, was not linear nor easily discernible on the surface, for reasons that go to the essence of Holmes as a person and a jurist. First, part of the attraction Holmes felt for the new generation of intellectuals that Frankfurter's circle personified stemmed from their perception of him as a figure of authority and eminence, being a representative of an older generation, a judge, and a major figure in American legal scholarship. But while Holmes found the company of his new friends invigorating and reveled in their praise, he did not share very many of their progressive ideas and took pains to disassociate himself from their political goals. ${ }^{108}$ His embrace of the values of a modern generation was thus elliptical, tentative, and qualified, despite the fact that his interest in preserving his role as an eminent but "youthful" figure was keen.

Second, Holmes was a judge, and his interest im gaining recognition was closely tied to how others assessed his judicial work. Given the very high value placed on jurisprudential consistency and integrity by his fellow judges and by the commumity of scholars who commented on judicial opinion, it was evident that Holmes, or any other judge interested in professional acclaim, would seek to convey an impression that any changes in his jurisprudential point of view could be seen as principled and internally consistent rather than idiosyncratic or ad hoc.

Finally, Holmes had a distinctive sensibility as a judge, one that was relatively rare among his professional peers. His greatest gratifications came from the philosophical and hterary dimensions of judicial decisionmaking, as distinguished from its more orthodox "legal" dimensions. Holmes was extremely interested in "finding a form of words" to express a particular argument; ${ }^{109}$ he was also extreinely interested in discerning

108. Holmes wrote Pollock in 1919, after reading a book suggested to Holmes by Laski, that the author, who described the twentieth century as the century of hope, held "a ratler deeper belief in the spiritual significance of man than I am able to entertain and a consequently greater faith on the upward and onward destiny of the race." Letter from Oliver Wendell Holmes to Sir Frederick Pollock (May 26, 1919), in 1 Holmes-Pollock LETTERS, supra note 105, at 13; see also Letter from Oliver Wendell Holmes to Sir Frederick Pollock (Apr. 23, 1910), in 1 Holmes-Pollock LETTERS, supra note 105, at 163 ("I don't disgnise my belief that the Sherman Act is a humbug based on economic ignorance and incompetence, and my disbelief that the Interstate Commerce Commission is a fit body to be entrusted with rate-making.").

109. In an August 4, 1924, conversation witl Felix Frankfurter, Justice Louis Brandeis said the following of Holmes:

Truth of [the] matter is he takes joy in the trick of working out what lie calls " $a$ form of words" in which to express desired result. He occasionally says, "I think I can find a form of words" to which I reply, "of course you can, you can find a form of words for anything."

Melvin I. Urofsky, The Brandeis-Frankfurter Conversations, 1985 SuP. CT. REv. 299, 334 (quoting Conversation between Louis D. Brandeis and Felix Frankfurter, in Chatham, Mass. (Aug. 4, 1924) (transcribed by Melvin I. Urofsky from notes contained in The Lewis Brandeis Papers (Harvard Law School))). 
the jurisprudential roots and philosophical groundings of that argument. $\mathrm{He}$ was only irregularly interested in the consequences of the result his opinion sought to justify, and strikingly uninterested in the doctrinal implications of his opinions for future cases. ${ }^{110} \mathrm{He}$ wrote opinions, in short, as if they were literary exercises or philosophical discourses, not as if they were doctrinal guides for others. These tendencies make his opinions arresting, memorable, and pithy, but often cryptic, elusive, and sometimes even deceptive as doctrinal forınulations; they make it difficult to render in any straightforward fashion the evolution of his perspective on a particular legal issue.

The process by which Holmes participated in the transforination of free speech jurisprudence was in the end an idiosyncratic process, despite its larger doctrinal implications. By treating Holmes' free speech cases as if they were the fornulations of an orthodox judicial-opinion writer, some scholars have been misled into emphasizing doctrinal continuity or contradiction, ${ }^{111}$ when Holmes was not particularly interested, except on a surface level, $m$ those dimensions of his opimions. Other scholars have been overly anxious to identify Holmes as the founder of a modern libertarian tradition of First Amendment analysis, suggesting that a libertarian posture reflected his "deepest thouglits" on free speecl. ${ }^{112}$ Neither view captures the complex set of variables and responses that resulted in Holnes participating in the modernization of free speech jurisprudence.

\section{IV}

\section{The Transformation of Holmes' First AMENDMENT JURISPRUDENCE}

\section{A. "Clear and Present Danger" and the Espionage Act Trilogy: Restating the Orthodox View}

Three years after Holmes' decision in Fox $v$. Washington, ${ }^{113}$ he gave some inkling that lie was beginning to reconsider his ortlodox views on freedom of speech. In the 1918 case of Toledo Newspaper Co. v. United States ${ }^{114}$ a majority of the Court upheld a judge's contempt citation of a newspaper imposed for remarks critical of the judge's conduct of a trial. The statute involved in Toledo Newspaper had provided that contempt citations could be issued in response to tlie "misbehavior of any person in [the] presence [of judges], or so near thereto as to obstruct the admin-

110. See infra text accompanying notes 413-17.

111. See supra note 11 and accompanying text.

112. Zechariah Chafee JR., Free Speech in the United States 86 (1941) (replaced original 1920 edition, id. at xi).

113. 236 U.S. 273 (1915).

114. 247 U.S. 402 (1918), overruled by Nye v. United States, 313 U.S. 33 (1941). 
istration of justice." "115 A majority of the Court read "so near" as meaning "tending to," stating that the test of whether such a statute could restrict First Amendment rights was "the character of the act done and its direct tendency to prevent and obstruct," 116 a restatement of the bad-tendency test. Holmes dissented, reading "so near as to obstruct" " as "so near as actually to obstruct-and not merely near enough to threaten a possible obstruction." 117 That language, and his vote to overturn the conviction, appeared imconsistent with his endorsement of the bad-tendency test in Fox. Moreover, his assumption that the case raised a First Amendment issue did not seem to square with his previously expressed view in Patterson v. Colorado ex rel. Attorney General ${ }^{118}$ that subsequent pumishment for objectionable speech did not violate the First Amendment at all, since the Amendment was confined to prior restraints against publication.

While Holmes' departure from Patterson in Toledo Newspaper foreshadowed his eventual abandonment of his orthodox views on free speech, his first postwar decisions in First Amendinent cases were hardly speech protective. In 1919 the Supreme Court considered four cases under the Espionage Act of 1917, a statute that sought to prevent persons from causing insubordination in the armed forces or obstructing the recruitment or enlistment of soldiers. ${ }^{119}$ In three of the cases, Schenck $v$. United States, ${ }^{120}$ Frohwerk v. United States, ${ }^{121}$ and Debs v. United States, ${ }^{122}$ the Court reached the merits of convictions obtained under the Act and concluded that the convictions did not violate the First Amendment. ${ }^{123}$ Holmes wrote unanimous opinions for the Court in each of the

115. Toledo, 247 U.S. at 418.

116. Id. at 419.

117. Id. at 423 .

118. 205 U.S. 454 (1907).

119. Espionage Act of 1917 , ch. 30,40 Stat. 217. The overwhelming number of prosecutions under the Espionage Act were brought under title I, section 3 of that Act, which provided that:

Whoever, when the United States is at war, shall willfully make or convey false reports or false statements with intent to interfere with the operation or success of the military or naval forces of the United States or to promote the success of its enemies and whoever, when the United States is at war, shall willfully cause or attempt to cause insubordination, disloyalty, mutiny, or refusal of duty, in the military or naval forces of the Umited States, or shall willfully obstruct the recruiting or enlistment service of the United States, to the injury of the service of the United States, shall be pumished by a fine of not more than $\$ 10,000$ or imprisonment for not more than twenty years, or both.

Id. tit. $1, \S 3,40$ Stat. at 217 .

120. 249 U.S. 47 (1919).

121. 249 U.S. 204 (1919).

122. 249 U.S. 211 (1919).

123. The Court dismissed Sugarman v. United States, 249 U.S. 182 (1919), for want of jurisdiction. In a unanimous opinion by Brandeis, the Court held that there had been no "substantial" constitutional issue properly raised in the case. Id. at 185. Sugarman dealt with a Socialist party member who had been convicted for describing World War I as a capitalist conspiracy in which workers should not participate. Id. at 183. The only basis for a constitutional 
three cases.

The three cases featured, for the first time in the twentieth-century history of free speech, extensive discussion of the First Amendment issues raised by prosecution under the Espionage Act. In all the cases, the government conceded that the First Amendment did not merely apply to prior restraints, ${ }^{124}$ but maintamed that the test for finding a violation of the Espionage Act was whether the language complained of had a "bad tendency"-in these instances a tendency to prevent or obstruct the war effort. Holmes' opinion in Schenck provided the central basis for the Court's decisions in all the cases.

The defendants im Schenck had been Socialist Party officials who had distributed leaflets to men who had been drafted to serve in World War I. ${ }^{125}$ The leaflets imtimated "that a conscript [was] little better than a convict," and "that conscription was despotism in its worst form and a monstrous wrong against humanity in the interest of Wall Street's chosen few." "126 The leaflet headings, addressed to the soldiers, read: " Do not subimit to intimidation' " and " "Assert Your Rights." "127

Holmes treated the facts of Schenck as an attempt to violate the Espionage Act, analogous to an attempt at criminal law. Under the crimmal-attempt rationale, speech was just another act whose legality was to be judged by the intentions of the actor and the act's tendency to bring about a legislatively prohibited evil. ${ }^{128}$ In his Schenck opinion, Holmes emphasized both of those elements. "Of course," he concluded, "the document would not have been sent unless it had been intended to have some effect, and we do not see what effect it could be expected to have upon persons subject to the draft except to influence them to obstruct the carrying of it out." 129 Under orthodox analysis, then, "intent" and "bad tendency" both had been found.

Holmes then considered, however, whether the fact that the circular distributed by the defendants was "protected by the First Amendment to the Constitution" 130 made any difference. He conceded that "the prohibition of laws abridging the freedom of speech is not confined to previous restraints, although to prevent them may have been the main purpose, as intimated in Patterson v. Colorado." 131 He also conceded that "in many places and im ordmary times the defendants im saying all that was said in

issue in the case was purportedly erroneous instructions on the First Amendment. See id. at 185. On review, however, the Court found that the instructions were adequate.

124. See Rabban, Emergence, supra note 12, at 1255-56 (discussing Debs).

125. Schenck, 249 U.S, at $49-50$.

126. Id. at $50-51$.

127. Id. at 51 .

128. Id. at 52.

129. Id. at 51 .

130. Id.

131. Id. at 51-52. 
the circular would have been within their constitutional rights." $132 \mathrm{He}$ then continued:

But the character of every act depends upon the circumstances in which it is done. The most stringent protection of free speech would not protect a man in falsely shouting fire in a theatre and causing a panic. ... The question in every case is whether the words used are used in such circumstances and are of such a nature as to create a clear and present danger that they will bring about the substantive evils that Congress has a right to prevent. It is a question of proximity and degree. . . . If the act, (speaking, or circulating a paper,) its tendency and the intent with which it is done are the sanie, we perceive no ground for saying that success alone warrants making the act a crime. ${ }^{133}$

This passage demonstrates how, at this stage of his career, Holmes' view of First Amendment issues was still shaped by his common-law experience, in particular his experience with the law of criminal attempts. As a Massachusetts judge, Holmes had implemented a view of criminalattempt law that focused on notions of intent and tendency, emphasizimg that the requisite intent to bring about an evil that the state had a right to prevent and the tendency to produce that evil were to be determined from the circumstances of the case. ${ }^{134}$ In two of his Massachusetts decisions, Commonwealth v. Kennedy ${ }^{135}$ and Commonwealth v. Peaslee, ${ }^{136}$ Holmes had addressed "intent" and "tendency" in terins of "proximity" and "degree." 137 He had also used the same terms in an earher Supreme Court decision, the criminal conspiracy case of Swift \& Co. v. United States, ${ }^{138}$ in which he stated that the distinction between "mere preparation" and an attempt was one of "proximity and degree."139

These previous opinions suggest that Holmes' "clear and present danger" language in Schenck was merely another version of formulas involving "proximity and degree." That speech was involved added nothing to the analysis. Spoken words urging resistance to the war were treated the same as an unsuccessful effort to poison a relative, as in Kennedy, or to burn down a building, as in Peaslee. Speech was, as Holmes told Harold Laski in July 1918, like "any other overt act that we don't like."140 As in the case of prohibitions on overt acts in the com-

132. Id. at 52.

133. Id. (citation omitted).

134. This view had first been promulgated by Holmes in his book, The Common Law. See Oliver Wendeli Holmes, JR., The Common LAW 65-66 (Boston, Little, Brown 1881).

135. 48 N.E. 770 (Mass. 1897).

136. 59 N.E. 55 (Mass. 1901).

137. See Peaslee, 59 N.E. at 56; Kennedy, 48 N.E. at 771-72.

138. 196 U.S. 375 (1905).

139. Id. at 402 .

140. Letter from Oliver Wendell Holmes to Harold J. Laski (July 7, 1918), in 1 HoLMES-LASKI LETTERS, supra note 1, at 161 . 
mon law of attempts, prohibitions on speech did not need to be closely tied to the imminence of success of the attempt.

Schenck then became the basis for the Court's decision to uphold the convictions in Frohwerk and Debs. Both cases were potentially distinguishable from Schenck on their facts. The defendant in Schenck had distributed leaflets directly to men who had been drafted. ${ }^{141}$ The only question in that case was whether the language in those leaflets demonstrated a tendency to encourage draftees to resist their conscription. In Frohwerk and Debs, by contrast, the speakers had issued general criticisms of the war effort and had not made any real effort to direct them to draftees. ${ }^{142}$ In Debs, the speaker had specifically restrained from urging draftees not to enlist. ${ }^{143}$

Holmes, however, did not treat these facts as making any difference. In Frohwerk he noted that "we have decided in [Schenck] that a person may be convicted of a conspiracy to obstruct recruiting by words of persuasion. ... . [S]o far as the language of the articles goes there is not much to choose between expressions to be found in them and those before us in Schenck v. United States."144 He conceded that "[i]t does not appear that there was any special effort to reach inen who were subject to the draft.".145 But on the record in Frohwerk, he concluded, "it is impossible to say that it might not have been found that the circulation of the paper was in quarters where a little breath would be enough to kindle a flame and tliat the fact was known and rehed upon by those who sent the paper out." 146

The Frohwerk case also included dicta suggesting that Holmes was treating it like an unsuccessful criminal attempt. He stated that "[w]e venture to beheve that neither Hamilton nor Madison, nor any other competent person then or later, ever supposed that to make criminal the counselling of a murder within the jurisdiction of Congress would be an unconstitutional interference with free speech."147 His comment seems umiecessary-no one at the time was suggesting that the First Amendment was an absolute-except to establish that an attempt to advise others to commit murder could be treated as an attempt to murder. Later in Frohwerk, Holmes noted that "[w]e do not lose our right to condemn either measures or inen because the Country is at war."148 Again, the cominent seems unnecessary unless Holmes was seeking to

\footnotetext{
141. Schenck, 249 U.S. at 50.

142. See Debs, 249 U.S. at 214-15; Frohwerk, 249 U.S. at 208.

143. See Debs, 249 U.S. at 213; see also infra text accompanying note 153.

144. Frohwerk, 249 U.S. at 206-07.

145. Id. at 208.

146. Id. at 209.

147. Id. at 206 .

148. Id. at 208.
} 
underscore the fact that the criminality of such condemnations should be treated as a question of proximity and degree, as embodied in formulas such as the "clear and present danger" dictum. But Holmes did not repeat that dictum in Frohwerk, and it is very difficult to see, despite Holmes' "kindle a flame" metaphor, ${ }^{149}$ how printing a circular intended for an audience of German-speaking socialists created a clear and present danger that the war effort would be obstructed.

The Debs case presented Holmes with another opportunity to apply his "attempts" analogy. This was the cause célébre of the Espionage Act cases, in which Eugene Debs, the Socialist Party candidate for President in 1912, was convicted of obstructing the war effort on the basis of a speech he made at the Socialists' convention. ${ }^{150}$ As Holmes conceded, Debs' "main theme" in the speech "was socialism, its growth, and a prophecy of its ultimate success." 151 Several particulars of Debs' speech, however, were made the basis of a criminal prosecution under the Espionage Act. Debs had alluded in the speech to a visit that he had made to three "loyal comrades" who were serving time in a workhouse for "aidimg and abetting another in failing to register for the draft." 152 In discussing that visit, Holmes said in his opimion, Debs had "said that he had to be prudent and might not be able to say all that he thought, thus intimating to his hearers that they might infer that he meant more."153 Holmes also noted that, in taking up the case of another Socialist who had been convicted of obstructing the enlistment service, Debs had "praised her for her loyalty to socialism ... and said that she was convicted on false testimony, under a rulimg that would seem incredible to him if he had not had some experience with a Federal Court."154 Finally, Holmes pointed out that Debs had said "I abhor war. I would oppose the war if I stood alone,"155 and that the Socialist Party had adopted an "Anti-war Proclamation and Program" " at its convention, which Debs had said that he "approved of ... in spirit and in substance."156

The logic of Holmes' approach to criminal attempts applied easily to Debs' acts. Holmes maimtained that the acts raised the possibility that "one purpose of the speech, whether incidental or not does not matter, was to oppose not only war in general but this war, and that the opposition was so expressed that its natural and intended effect would be to

149. See supra text accompanying note 146.

150. Debs, 249 U.S. at 212.

151. Id.

152. Id. at 213.

153. Id.

154. Id.

155. Id. at 214 .

156. Id. at 215 . 
obstruct recruiting." $157 \mathrm{He}$ then concluded that "[i]f that was intended and if, in all the circumstances, that would be its probable effect, [Debs' speech] would not be protected by reason of its being part of a general program and expressions of a general and conscientious belief."158 According to Holmes, Debs' statement approving the Socialist Party's antiwar platform was telling in this regard. "Evidence that the defendant accepted this view and this declaration of his duties at the time that he made that speech," Holmes said, "is evidence that if in that speech he used words tending to obstruct the recruiting service he ineant that they should have that effect."159

Holmes' analysis of the issues in Debs is very difficult to square with his "clear and present danger" dictum in Schenck. Holmes argued that since Debs had accepted the antiwar platform of the Sociahist Party and used "obstructiomist" language in his speech, Debs intended to obstruct the recruiting service. There was no evidence, however, that Debs had used "words tending to obstruct the recruiting service" unless opposition to war itself had that tendency. The inost that could be said of Debs' speech was that he had praised fellow socialists who had been convicted of obstructing the war effort and hinted that he would like to say more. Holmes' argument therefore makes no sense if Debs did not use any language that could fairly be labeled obstructionist. In Holmes' hands Debs thus established the primciple that one could be convicted for opposing war generally.

Debs therefore was not a "clear and present danger" case unless Holmes was treating that formula as inerely codifying the "tendency" element of criminal-atteinpt law. ${ }^{160}$ While Debs' speech inight have had a tendency to obstruct the war effort-assuming that soine of his audience, sharing his antiwar sentiments and encouraged by his praise for convicted obstructionsts, might have decided to encourage draftees to resist-it surely had not created a "clear and present danger" that the war effort would be obstructed. Schenck, Frohwerk, and Debs, taken together, suggest that Holmes' "clear and present danger" test was simply a restatement of "attempts" language found in his earlier opinions. An example of such language can be found in Swift \& Co. v. United States, in which Holmes had said that "[w]here acts are not sufficient in themselves to produce a result ..., an intent to bring it to pass is necessary in order to produce a dangerous probability that it will happen." 161 If this conclusion is accurate, Holnes' Espionage Act decisions did not

\footnotetext{
157. Id. at 214-15.

158. Id. at 215 .

159. Id. at 216.

160. See supra text accompanying notes 133-38 (discussing influence of the law of criminal attempts on Holmes' view of First Amendment issues).

161. 196 U.S. 375,396 (1905).
} 
significantly modify his earlier free speech jurisprudence. In the three cases, the only clear modification was Holmes' abandonment of the "prior restraints" interpretation of constitutional provisions affecting speech.

B. Commentator Response to the Espionage Act Decisions: The Dialogue with Holmes ${ }^{162}$

After the three Espionage Act cases came down in the spring of 1919 , a groundswell of criticism of the opinions from progressive intellectuals surfaced. While the precise causes for that groundswell cannot be determined with certainty, there are several possible factors. With the end of World War I one of the most obvious and settled rationales for suppressing speech, fostering the national interest in wartinie, diminished in significance. At the same tine a growing consciousness among Americans of the doctrines of collectivist European ideologies, such as sociahism or syndicalism, had begun to emerge, sparked by the formation of the Communist Third Interuational in March 1919, bombing of persons alleged to be political radicals in May or June of that year, and publicized strikes among pohice, steel workers, and coal workers in the fall of $1919 .{ }^{163}$ The apparent emergence of this radical ideology as a moving force in American industrial life precipitated a "Red Scare," in which federal and state law enforceinent authorities sought to expose the activities of radicals and to curb their influence by restricting their opportunities to speak. Those reacting to the Red Scare saw the suppression of radical doctrimes allegedly desigued to foster industrial unrest as comparable to the suppression of "enemy" actions in wartime. ${ }^{164}$

The extension of repressive tactics toward controversial speech from the wartime to the Red Scare context alarmed a number of progressive intellectuals. During the year 1919, editorials in The New Republic, regarded by these progressives as their principal intellectual forum, increasingly described the tactics of those caught up in the Red Scare as excessive and hysterical, and called for a reaffirmance of the values of protecting free speech in a deinocratic society. ${ }^{165}$

Holmes had becoine aware of The New Republic shortly after its

162. This section tracks material previously covered in Gunther, supra note 10 , at $732-43$, and Rabban, Emergence, supra note 12, at 1278-301. While its conclusions support those of Gunther and Rabban, its emphasis is primarily on Holmes, particularly his response to commentary and the relationship between that response and his altered perspective on free speech issues after his $A$ brams dissent.

163. See William E. Leuchtenberg, The Perils of Prosperity 1914-32, at 69, 73-76 (1958); Robert K. MURRaY, Red SCARE: A StUdy IN NATIONAL History, 1919-1920, at 92-94, 121-22 (1955).

164. See Murray, supra note 163 , at 122-65.

165. See Noble, supra note 20, at 397,400 . On the role of The New Republic as an organ of progressive intellectuals, see Charles Forcey, THE Crossroads OF Liberalism (1961) and 
founding in 1914, and regularly discussed The New Republic articles and editorials in his correspondence with Felix Frankfurter and Herbert Laski. ${ }^{166}$ In May of 1919, an article by Ernst Freund appeared in The New Republic that was conspicuously critical of Holmes' opinion in the Debs case. Freund claimed Holmes had taken "the very essentials of the entire problem for granted"167 by permitting the jury "to find a tendency and an intent to obstruct recruiting" when there was "nothing to show actual obstruction or an atteinpt to interfere with any of the [recruitment] processes." 168 "[T]o be permitted to agitate at your own peril, subject to a jury's guessing at motive, tendency and possible effect," Freund argued, "makes the right of free speech a precarious gift."169 Freund thought Holmes' "fire in a crowded theatre" analogy unsuited to "pohtical offenses" and suggested that Holmes' view of free speech was an "unsafe doctrine" if "it has to be made plausible by a parallel so manifestly inappropriate." 170

Holmes had already become aware of opposition to his Debs opinion before Freund's article had appeared and had responded to that opposition with a certain defensiveness. He wrote Frederick Pollock on April 5,1919 , that he was "beginning to get stupid letters of protest against a decision that Debs, a noted agitator, was rightly convicted of obstrncting the recruiting service so far as the law was concerned."171 He went on:

I wondered that the Government should press the case to a hearing before us, as the inevitable result was that fools, knaves, and ignorant persons were bound to say he was convicted because he was a dangerous agitator and that obstructing the draft was a pretence.... There was a lot of jaw about free speech, which I dealt with somewhat summarily in an [earlier] case-Schenck v. U.S. . . As it happens I should go farther probably than the inajority in favor of it, and I daresay it was partly on that account that the C.J. assigned the case to me. ${ }^{172}$

With this letter Holines began a pattern of correspondence with several commentators in which he expressed regret about the Espionage Act

Christopher LASCH, THE NEW RADiCALISM IN AMERICA 181-224 (1965) (chapter entitled "The New Republic and the War: 'An Unanalyzable Feeling' ").

166. See, e.g., Letter from Harold J. Laski to Oliver Wendell Holmes (July 19, 1918), in 1 HoLmes-LASKI LeTTERS, supra note 1, at 5 ("Please don't fail to read Phil Littell in this week's New Republic."); Letter from Oliver Wendell Holmes to Felix Frankfurter (Jan. 28, 1916), in Holmes Papers, supra note 13 ("The New Republic is on my table but I am [behind and] hav[e] been frightfully busy. I note your recommendations.").

167. Ernst Freund, The Debs Case and Freedom of Speech, NEw Republic, May 3, 1919, at 13,14 .

168. Id. at 13 .

169. Id. at 14 .

170. Id.

171. Letter from Oliver Wendell Holmes to Sir Frederick Pollock (Apr. 5, 1919), in 2 HoLmesPollock LetTERS, supra note 105, at 7.

172. Id. (footnotes omitted). 
convictions and personal sympathy for Debs and the other defendants. At the same time, however, Holmes reaffirmed his view that the cases were rightly decided. Two weeks later, for example, he wrote Pollock:

Of course there were people who pitched into the Court for sending Debs to prison under the espionage act, but there was no doubt that the Jury was warranted in finding him guilty or that the act was Constitutional. Now I hope the President will pardon him and some other poor devils with whom I have more sympathy. ${ }^{173}$

In the meantime Holmes sent Harold Laski his opimions in the Espionage Act cases. He felt compelled to add:

I greatly regretted having to write them-and (between ourselves) that the Government pressed them to a hearing. Of course I know that donkeys and knaves would represent us as concurring in the condemnation of Debs because he was a dangerous agitator... . But on the only questions before us I could not doubt about the law. The federal judges seem to me (again between ourselves) to have got hysterical about the war. I should think the President when he gets through with his present amusements might do some pardoning. ${ }^{174}$

Laski's response was a lukewarm endorsement of Holmes' opimions. He called Holmes' cry-of-fire-in-a-theatre analogy "excellent" and conceded that "though I say it with deep regret [the decisions] are very convincing." 175 Laski added, however, that "I am not sure that I should not have liked the hine to be drawn a little tighter about executive discretion."176 Two weeks later, Holmes wrote again to Laski, informing him that the New Republic had written an editorial about Debs. The editorial stated that "[t] $]$ here is no doubt about the legality of his conviction. . . . [But] to let Debs serve his sentence would be both cruel and blind."177 Holmes told Laski that he found the editorial "exactly right," but felt "it would not be proper... to say so publicly."178

On May 11, at the end of a letter discussing poetry, English literature, and a controversy brewing at Harvard Law School over some alumni's reaction to Felix Frankfurter, Laski wrote, "I am eager to hear if you read Freund in the New Republic of May 3rd and if you were at all influenced by his analysis." 179 The first part of that question was an idle

173. Letter from Oliver Wendell Holmes to Sir Frederick Pollock (Apr. 27, 1919), in 2 HOLMES-POLLOCK LETTERS, supra note 105, at 11.

174. Letter from Oliver Wendell Holmes to Harold J. Laski (Mar. 16, 1919), in 1 HolmesLASKI LETTERS, supra note 1, at 190.

175. Letter from Harold J. Laski to Oliver Wendell Holmes (Mar. 18, 1919), in 1 HolmesLASKI LETTERS, supra note 1, at 191.

176. Id.

177. Editorial Note, New RePuBlic, Apr. 19, 1919, at 362.

178. Letter from Oliver Wendell Holmes to Harold J. Laski (Apr. 20, 1919), in 1 HoLMESLASKI LETTERS, supra note 1, at 197 (footnote omitted).

179. Letter from Harold J. Laski to Oliver Wendell Holmes (May 11, 1919), in 1 HolmesLASK1 LETTERS, supra note 1, at 201-02. 
one, for Holmes had already fired off a letter to Laski in which he had enclosed a letter he had prepared for Herbert Croly, editor of The New Republic, in response to the Freund article. Holmes wrote to Laski that he had "decided not to send" the letter to Croly "as soine theines may becoine burning."180 The letter was consistent with the defensive stance Holmes had adopted in his previous discussions of the Espionage Act cases. It read in part as follows:

As long ago as 1908 when I wrote Harriman v. I.C.C. it seemed to me that we so long had enjoyed the advantages protected by bills of rights that we had forgotten-it used sometimes to seem to me that the New Republic had forgotten-that they had had to be fought for and could not be kept unless we were willing to fight for them. . . . As I spoke of [that theme] to my secretary ... he called my attention to the article on the Debs case which I had not seen. You had a short paragraph in an earher number that struck me as exactly right. This article appeared to me less so if I understood its imphications. The constitutionality of the act so far as the clauses concerning obstructing the recruiting service are involved was passed upon in Schenck v. U.S. and so all that was needed im the Debs case was to refer to that decision, and, given the finding of the jury, in my opinion it was impossible to have a rational doubt about the law. Freund's objection to a jury "guessing at motive, tendency, and possible effect" is an objection to pretty much the whole body of the law, which for thirty years I have made my brethren smile by insisting to be everywhere a matter of degree. ... I hated to have to write the Debs case and still more those of the other poor devils before us the same day and the week before. I could not see the wisdom of pressing the cases, especially when the fighting was over and I think it quite possible that if I had been on the jury I should have been for acquittal but I cannot doubt that there was evidence warranting a conviction on the disputed issues of fact. Moreover I thimk the clauses under consideration not only were constitutional but were proper enough while the war was on. ... But in the main I am for aeration of all effervescing convictions-there is no way so quick for letting them get flat. ${ }^{181}$

The Croly letter is interesting in several respects. First, even though Holmes had previously informed Laski that he thought it improper to tell The New Republic editors that their editorial on the Debs case was "exactly right," Holines had been initially inclined to send Croly a letter with that very language in it. Sending the letter to Laski, who knew Croly well, made it quite possible that Croly would learn of Holmes' views. Second, Holmes' statement that Debs was foreclosed by Schenck was only persuasive if both Schenck and Debs were bad-tendency cases,

180. Letter from Oliver Wendell Holmes to Harold J. Laski (May 13, 1919), in 1 HoLMEsLASKI LETTERS, supra note 1, at 202.

181. Letter from Oliver Wendell Holmes to Herbert Croly (May 12, 1919), in 1 HoLmEs-LASKI LETTERS, supra note 1, at 203-04 (citation omitted) (footnote omitted). 
because there was no evidence that Debs' speech had created a "clear and present danger" that the recruitment of troops would be obstructed. Holmes added that "it was impossible to have a rational doubt" about the constitutionality of the statute because the jury had found against Debs. But the jury's finding might have been based on a imstaken mipression that persons could be convicted under the Espionage Act for voicing a general opposition to war.

Holmes next repeated his view that all legal questions were questions of degree, a statement which was unresponsive to Freund's argument about juries' "guessing" in Espionage Act cases. Freund's point was not that the apphication of any test or standard directed toward determining whether speech could be suppressed in a given case involved guesswork. It was that the bad-tendency test unduly permitted juries to guess whether "bad" inferences could be inade from very general statements, and thus permitted the Act to serve as a ineans of restricting speech that was inerely unpopular. ${ }^{182}$

Along with emphasizing that his opimions in the Espionage Act cases were dictated by law, Holmes stressed that they were personally abhorrent. He confessed that he "hated" to "have to write" the Debs case; that he was syinpathetic to Debs and even more so to the other defendants in Espionage Act cases; that if he had been on the jury in Debs he would have been for acquittal; ${ }^{183}$ and that his general attitude toward speech was to allow "effervescing convictions" to be "aerat[ed]" so that they might "get flat" with public exposure. He even intimated that soine of the Espionage Act might be unconstitutional by underlining "clauses under consideration" in his remarks on constitutionality, and stated that now that the war was over it made no sense to prosecute "obstructionnst" speakers under the Act.

The defensiveness Holmes exhibited in responding to criticism of Debs, as illustrated by his letters to Laski and Croly, could have been taken by his young friends as a gesture of reassurance. The letters inight have conveyed a message to Holmes' progressive supporters that he had not deserted thein on free speech even though he had been constrained in the Espionage Act cases; that he bore a particular burden, having written the opmion in Schenck, but that he was not unsympathetic to free speech arguinents. The gesture could even have been taken as an invitation to continue talking to him about the subject.

At the time that Holines was corresponding with Laski and Croly

182. See Freund, supra note 167 , at 15 .

183. This view was not consistent with what he expressed to Pollock, see supra text accompanying note 173, and to Wigmore. He told Wigmore that the jury's finding in Debs was correct. See Letter from Oliver Wendell Holmes to John P. Wigmore (June 7, 1919), in Holmes Papers, supra note 13. 
about free speech, he had already had discussions with yet another progressive intellectual, Learned Hand, on the saine subject. In June 1918, Holmes had encountered Learned Hand on a train, and the two inen had had a conversation about the First Amendment. ${ }^{184}$ The discussion might have been proinpted by the fact that Hand himself had previously issued an opinion in the case of Masses Publishing Co. v. Patten, ${ }^{185}$ in which he had advanced a hibertarian interpretation of the First Amendunent. In Masses the Postmaster General sought to exclude The Masses magazine from the mails under the Espionage Act on the grounds that it was willfully critical of the war effort. ${ }^{186}$ Hand granted an injunction against the Postmaster General. ${ }^{187}$ In the process, he articulated a test for evaluating the constitutionality of First Amendment challenges to legislation that focused on "direct incitement to violent resistance."188 In the Espionage Act cases, under Hand's test the question would not have been whether "the indirect result of the language might be to arouse a seditious disposition," but whether "the language directly advocated resistance to the draft." 189

Hand's direct-incitement test was rejected, on appeal, by the U.S. Court of Appeals for the Second Circuit, and was imphicitly not regarded as a plausible approach to First Amendinent issues during Holines' tenure. ${ }^{190}$ Hand, however, continued to believe in it and might have defended it in his train conversation with Holnes.

After the conversation the two inen exchanged letters. Hand's letter began by referring to a comment in the conversation in which he and Holmes had discussed the role of tolerance for the opinions of others in free speech theory. He argued that Holmes' view that there was a "sacred right to kill the other fellow when he disagrees," which had "silenced" Hand when Holmes said it, ${ }^{191}$ needed to be limited. The right did not exist, Hand asserted, when "the victims insist upon saying things which look against Provisional Hypothesis Number Twenty-Six, the verification of which to date may be found in its proper place in the card catalogue," because if they are "spared, other cards may be added under

184. Gunther, supra note 10 , at 732 .

185. 244 F. 535 (S.D.N.Y.), rev'd, 246 F. 24 (2d Cir. 1917).

186. Id. at $538-39$.

187. Id. at 543 .

188. Id. at 540 .

189. Id. at 542 .

190. See Masses Publishing Co. v. Patten, 246 F. 24 (2d Cir. 1917). Hand himself intimated in correspondence to Holmes that no other court had endorsed his approach. See Letter from Learned Hand to Oliver Wendell Holmes (late Mar. 1919), in Holmes Papers, quoted in Gunther, supra note 10, at 758; Letter from Learned Hand to Oliver Wendell Holmes (Mar. 1919), in Holmes Papers, supra note 13.

191. Letter from Learned Hand to Oliver Wendell Holmes (June 22, 1918), in Holmes Papers, supra note 13. 
that sub-title which will have, perhaps, an important modification."192

Holmes responded that "free speech stands no differently than freedom from vaccination." $193 \mathrm{He}$ felt that if the legislature believed strongly enough in the evil of certain acts to enact legislation prohibiting thein, the possibility that the belief imight be wrong would be wholly irrelevant. While "[t]he occasions would be rarer when you cared enough to stop it," Holmes felt, "if for any reason you did care enough you wouldn't care a damn for the suggestion that you were acting on a provisional hypothesis and might be wrong. That is the condition of every act." 194 He was not mclined to think that the possibility that speech imight lead those in power to alter their policies in the future was a sufficient justification for invariably permitting it im the present.

The correspondence then lapsed until February 1919, when Holmes wrote Hand that he had read Hand's Masses opimion and "will assume for present purposes that I should come to a different result." $195 \mathrm{He}$ added, however, that "few judges ... could have put their view with such force or in such admirable form." 196 The date of that letter suggests that Holmes 1might have been prompted to read Masses in connection with the Espionage Act cases, the first of which were handed down six days later. When the Espionage Act opmions were announced, Hand read them and wrote Holines, prefacing his letter by saying that "this is positively my last appearance $\mathrm{m}$ the role of hiberator." 197 While stating that Debs "was guilty under any rule conceivably apphicable,"198 Hand criticized Holmes' approach. He thought it dependent on an assumed causal relationship between words and their future impact. "In nature," he argued, "the causal sequence is perfect, but responsibility does not go pari passu." 199 Hand did "not understand that the rule of responsibility for speecll" had ever been that "the result is known as likely to follow."200 In his view "[ $t]$ he responsibility ouly began when the words were directly an incitement."201 $\mathrm{He}$ added that he thought "the test of motive" was a "dangerous test," since "[j]uries won't much regard the difference between the probable result of the words and the purposes of the

192. Id.

193. Letter from Oliver Wendell Holmes to Learned Hand (June 24, 1918), in Holmes Papers, supra note 13.

194. Id.

195. Letter from Oliver Wendell Holmes to Learned Hand (Feb. 25, 1919), in Holmes Papers, supra note 13.

196. Id.

197. Letter from Learned Hand to Oliver Wendell Holmes (late Mar. 1919), in Holmes Papers, supra note 13.

198. Id.

199. Id.

200. Id.

201. Id. 
utterer."202 In short, Hand reiterated his Masses test as the touchstone for First Amendment cases.

Holmes responded im a letter that illustrates, in the words of Gerald Gunther, "the primitiveness of Holmes's first amendment thinking at that time."203 "I am afraid," Holmes began, "that I don't quite get your point." 204 He noted that he had "said nothing" in the Debs case "except to note that . . . the jury must be taken to have found that Debs's speech was intended to obstruct and tended to obstruct."205 He then claimed that Hand's statement that "the responsibility only began when the words were directly an mcitement" was the same as his "clear and present danger" formulation in Schenck. "I take it," he said, "that you agree that words inay constitute an obstruction within the statute, even without proof that the obstruction was successful to the point of preventing recruiting. . . . So I don't know . . . how we differ so far as your letter goes."206

The point of Hand's letter, of course, was that any causal connections between a speaker's words and the evils that the Espionage Act sought to prevent had to be predicated on the speaker's directly advocating those evils. For Hand, whether the speaker "intended" the proscribed result or whether the speaker's language "tended" to accomplish that result was irrelevant if the speaker had not directly advocated illegal activity. Holmes' "clear and present danger" formulation was not responsive to that argument. Nor was Holmes' statement that since Hand agreed that a speaker could be convicted even if his speech had been unsuccessful in obstructing recruiting, he and Hand did not disagree in their basic approaches. Hand would prosecute only for direct incitements of illegal activity, regardless of whether they were successful. Holnes would allow prosecution for speech that could be taken as "tending" to mcite illegal activity even though the speaker stopped short of doing so directly. The approaches were sufficiently different that Hand had written Ernst Freund, four days after Freund's critique of Debs had appeared, that " 'I was chagrined that Justice Holmes did not line up on our side." "207 Hand added to Freund that "I have so far been unable to make [Holmes] see that he and we have any real differences." "208

The exchange with Hand demonstrated that while Holmes thought

202. Id.

203. Gunther, supra note 10 , at 741 .

204. Letter from Oliver Wendell Holmes to Learned Hand (Apr. 3, 1919), in Holmes Papers, supra note 13.

205. Id.

206. Id.

207. Gunther, supra note 10, at 736 (quoting Letter from Learned Hand to Ernst Freund (May

7, 1919)).

208. Id. 
his "clear and present danger" test to be controlling in free speech cases (even though he had not referred to it in the Frohwerk and Debs cases), he treated it as merely declarative of the state of the law governing both criminal attempts and criminal appeals in speech cases. "Clear and present danger" encapsulated the fact that the relevant inquiries in those cases focused on the speaker's (or actor's) words or acts, how closely they were connected to illegal activity, and whether, based on the closeness of that connection, the speaker could be presumed to have "intended" the illegal activity to take place. The test was not a limit on the scope of restrictions on free speech; it was a formula for describing how one analyzed "dangerous" speeches and other "atteinpts."

Thus as late as May 1919, when he wrote Croly defending his Espionage Act opinions, Holmes, however much he wanted to convey the impression that he was sympathetic to the position of the defendants in those cases, continued to treat unpopular speech as another "act you didn't like" and did not regard his "clear and present danger" dictum as a test emphasizing the limits on governmental suppression of speech. By Noveinber 1919, however, Holines had issued his dissent in Abrams v. United States, ${ }^{209}$ and a month later, in a letter to Pollock discussing his dissent, Holmes said that "[a]s the Debs case and two others were assigned to me, in which the convictions were upheld, I thought it proper to state what I thought the limits of the doctrine."210 From his Abrams dissent until the end of his career Holmes treated "clear and present danger" as a limiting test, an alternative to the bad-tendency test, and accordingly treated free speech problems as distinguishable froin crimmnal attempts.

Abrams thus represented a inajor change in Holmes' posture in free speech cases, one that could not have been anticipated by his progressive friends on the basis of their correspondence with him im the few inonths after the Espionage Act trilogy. The correspondence with Laski and Hand, the editorials in The New Republic, and Ernst Freund's article had penetrated Holmes' consciousness, however, as his defensive response to criticism of the Debs case suggested. In addition, over the summer of 1919 his young friends continued to encourage hin to rethink free speech issues, and eventually he encountered a formulation of the rationale for increased protection for speech that resonated. This was the formulation advanced by Zechariah Chafee, who combined an artful reconstruction of Holines' treatment of speech in the Espionage Act cases with a refor-

209. 250 U.S. 616, 624-31 (1919) (Holmes, J., dissenting).

210. Letter from Oliver Wendell Holmes to Sir Frederick Pollock (Dec. 14, 1919), in 2 HOLMES-POLLOCK LETTERS, supra note 105, at 32 (footnote omitted). Holmes wrote similar letters to Nina Gray and Albert Beveridge at the same time. See Letter from Oliver Wendell Holmes to Nina Gray (Dec. 10, 1919), in Holmes Papers, supra note 13; Letter from Oliver Wendell Holmes to Albert Beveridge (Dec. 8, 1919), in Holmes Papers, supra note 13. 
mulation of the philosophical basis for protecting speech rights. Chafee's reformulation deemphasized the argument that speech was one of many hiberties held against the state and emphasized the "social interest" in protecting speech as a means of furthering "the discovery and spread of truth on subjects of general concern"211 in a democratic society.

In late July 1919, Laski invited Holmes, who was summering in Beverly Farms, Massachusetts, to tea im Cambridge to meet Zechariah Chafee, then an assistant professor at Harvard Law School. ${ }^{212}$ Prior to that meeting Laski had given Holmes a copy of Chafee's June, 1919, article. ${ }^{213}$ Laski heartily approved of the article, which mcluded, in addition to its discussion of the Espionage Act cases, an argument that the Court's pre-Espionage Act treatment of free speech cases had been speech protective. ${ }^{214}$ The article mcluded a plea for enhanced recoguition of the limits the Amendment imposed on the power to suppress dissident speech, ${ }^{215}$ and Laski wrote Chafee that "we must fight on it" "with Holmes at the tea. ${ }^{216}$ " 'I've read it twice," " Laski indicated, " 'and I'll go to the stake for every word." "217

Although Holmes' correspondence supplies no direct evidence that he had read Chafee's article, either before or after the tea, he had undoubtedly done so. The article was sent to him during a time, the early summer of 1919 , when he had the leisure to read. It involved a subject about which Holmes was deeply interested and extensively discussed opimions he had written. Moreover, it had been critical of him and had been written by a person whose opimion he might presumptively have granted some weight, a young faculty member at Harvard Law School who had contributed to The New Republic.

Several statements in Chafee's article imight have attracted Holmes' attention. First, Chafee said that all of the Espionage Act cases except Debs were "clear cases of incitement to resist the draft, so that no real question of free speech arose." 218 That statement was essentially inaccurate, but it conformed to Holmes' general view of the cases. Next, Chafee identified Holmes' "clear and present danger" dictum as the

211. Chafee made this argument, in identical language, in two articles. See Chafee, Speech in War Time, supra note 22, at 956-57; Chafee, Freedom of Speech, supra note 22, at 67.

212. See Ragan, supra note 10, at 43 (citing Letter from Harold J. Laski to Zechariah Chafee, Jr. (July 23, 1919), in Zechariah Chafee, Jr., Papers (Harvard Law School)).

213. Id. at 43. The article Laski gave to Holmes was Chafee, Speech in War Time, supra note 22.

214. Ragan, supra note 10, at 38-43; see also Chafee, Speech in War Time, supra note 22, at 955-59.

215. Chaffe, Speech in War Time, supra note 22, at 934, 957, 973.

216. See Ragan, supra note 10, at 43 (quoting Letter from Harold J. Laski to Zechariah Chafee, Jr. (July 23, 1919), in Zechariah Chafee, Jr., Papers (Harvard Law Library)).

217. Id. (quoting Letter from Hárold J. Laski to Zechariah Chafee, Jr. (July 23, 1919), in Zechariah Chafee, Jr., Papers (Harvard Law Library)).

218. Chafee, Speech in War Time, supra note 22, at 967 (footnote omitted). 
"Supreme Court test"219 for free speech cases. He then proceeded to construe it in a fashion that was remarkable, but sympathetic to Holmes. After argumg that earhier views of the First Amendment were mcompatible with the bad-tendency test ${ }^{220}$ and consistent with Hand's directmcitement test, ${ }^{221}$ Chafee claimed that Holmes' dictum "substantially agree[d]" with the latter test and with "the history and pohtical purpose of the First Amendment."222 He said that Holmes, im his "clear and present danger" test, had "draw[n] the boundary lime very close to the test of mcitement at common law and clearly ma[de] the punishment of words for their bad tendency impossible."223

In light of Frohwerk and Debs, this last statement was astonishing. Chafee attempted to reconcile it with those cases by suggesting that the defendant in Frohwerk had clearly incited others to resist the draft, ${ }^{224}$ and that in Debs Holmes had unfortunately ignored the "clear and present danger" test. ${ }^{225}$ Both suggestions provide clues to Chafee's purpose in writing the article.

The statement about Frohwerk was incorrect: the defendant had only inade general statements critical of existing governmental policy. Frohwerk, however, was a difficult case for Chafee's interpretation of Holines' approach to the Espionage Act. In his Frohwerk opinion Holines had openly indicated the possible tendency in the defendant's circulars to inipede the war effort and had not nentioned the "clear and present danger" dictum. ${ }^{226}$ Thus, Chafee had nothing to gain froin a detailed analysis of Frohwerk, which he did not undertake.

The stateinent about Debs, however, was very likely intended to touch a nerve in Holmes. Debs was the case for which Holmes had received the severest criticisn, and the result in Debs, because of the defendant's deliberate effort to avoid making any exphicit statement in support of resistance to the draft, was arguably the inost vuhierable of the Espionage Act cases. Chafee devoted considerable attention to Holmes' opinion in Debs. If Holmes had applied the "clear and present danger" test in Debs, Chafee argued, it was "hard to see how [Debs] could have been held guilty."227 Holmes had permitted the jury to convict Debs "inerely because [it] thought his speech had a tendency to bring about resistance to the draft":.228 he had treated the verdict as

219. Id. at 968.

220. Id. at $949-53$.

221. Id. at $960-64$.

222. Id. at 967.

223. Id.

224. See id. at $967 \&$ n.122.

225. See id. at 968 .

226. See Frohwerk v. United States, 249 U.S. 204, 209 (1919).

227. Chafee, Speech in War Time, supra note 22, at 967-68.

228. Id. at 968 . 
"proof that actual interference with the war was intended and was the proximate effect of the words used." 229 For the "clear and present danger" test to "mean anything more than a passing observation," Chafee maintained, "it must be used to upset convictions for words when the trial judge did not insist that they must create 'a clear and present danger' of overt acts."230 Only then would the test be functioning as it should: "to emphasize the social interest behind free speech, and show the need of balancing even in war time."231 In Debs, Chafee concluded, Holmes "did nothing to emphasize the social interest behind free speech."232 Holmes' "liberalism," Chafee concluded, seemed "held in abeyance" in the case. ${ }^{233}$

The option Chafee seemed to be implicitly posing for Holmes was that if Holmes wanted his clear and present danger dictum to emerge as the Court's test for First Amendment cases, he needed to apply it with some degree of rigor, not ignore it. Chafee even provided Holmes with a philosophical basis for treating the "clear and present danger" test as a test settimg forth the limits on governmental suppression of speech: the assumption that "[o]ne of the most important purposes of society and government is the discovery and spread of truth."234 Those familiar with Holmes' Abrams dissent will recognize that Holmes implicitly accepted Chafee's offer. He restated the "clear and present danger" test in a more rigorous fashion, separated First Amendment analysis from the common law of attempts, and reached a result that was clearly incompatible with Schenck even though purportedly based on the same analytical criteria.

It is worth noting, however, that at the tea at which Holmes and Chafee met for the first time and "fought" about free speech doctrine, Chafee had no sense that he had brought Holmes over to his point of view. In September 1919, Chafee wrote Judge Charles Amidon that while Holmes had indicated at the tea that as a juror he would have voted to acquit Debs, as a judge he was "inclined to allow a very wide latitude to Congressional discretion in the carrying on of the war," " and that he "could not have gone behind the jury verdict" " in Debs. ${ }^{235}$ Chafee added that Holmes' "omission to state the principles" "governing free speech cases was typical of federal judges at the time. ${ }^{236}$

Chafee's behef that Holmes remained unconvinced after their ineet-

229. Id.

230. Id.

231. Id.

232. Id.

233. Id. at 969.

234. Id. at 956 .

235. Rabban, Emergence, supra note 12, at 1315 (quoting Letter from Zechariah Chafee, Jr., to Judge Charles Amidon (Sept. 30, 1919), in Zechariah Chafee, Jr., Papers (Harvard Law Library)).

236. Id. 
ing should not be considered strong evidence that Chafee's analysis had not affected Holmes. Holmes was, as we have seen, defensive about criticisin; ${ }^{237}$ in addition, he was disinclined to make public corrections ${ }^{238}$ and extremely sparing $\mathrm{m}$ his acknowledgment of the influence of others on his ideas. ${ }^{239}$ When confronted in a discussion with two younger men who were inclimed to fight him on the Debs case, Holmes was not likely to confess error.

There is also reason to suspect that Holmes had incentives to accept Chafee's implicit invitation. Holmes had taken pains to commumicate his personal behief that the Espionage Act prosecutions should not have been brought and his hope that the defendants would be pardoned. He also must have sensed, from the groundswell of criticism that Debs had stimulated and froin The New Republic's adoption of a hibertarian position on free speech issues, that free speech jurisprudence was at a pressure poimt in its history. Fimally, he prided himself on not being "hysterical" with respect to unpopular speech im the same way that he was not "larınoyant" on issues that appealed to "sentiment."240 His early and prominent involvement with the Espionage Act cases had given him an opportunity to fashion Court doctrine im an area that promised to be of widespread public interest. Chafee's reconstruction of "clear and present danger" and reforinulation of the philosophical basis of free speech had provided him with opportunities to rethink that doctrine: Abrams would give him an early chance to express his thoughts.

The above analysis of the Schenck-Abrams sequence rests on two assumptions: that when Holmes einployed the phrase "clear and present" danger im Schenck, he had not moved very far from his previous orthodox response to free speech cases, and that it was the artful recharacterization of "clear and present" danger by Chafee, coming on the heels of other comments by young acquaintances of Holmes about free speech, that caused him to rethink his perspective. A letter Holmes wrote Chafee in 1922 provides indirect support for both of these assuinptions.

In the letter Holmes gave an account of the origins of "clear and present danger" that suggested that he never intended the dictum to

237. See 1 HowE, supra note 88 , at $137,230-31$.

238. See 1 id. at 137.

239. See 2 Howe, supra note 96, at 248.

240. The reference is to Holmes' opinion in United Zinc \& Chemical Co. v. Britt, 258 U.S. 268 (1922) (reversing a judgment concerning two child trespassers who died after swinıming in a pool containing poisonous chemicals). A dissent by Justice John Clarke criticized the niajority's position as "harsh." Id. at 280 (Clarke, J., dissenting). Holmes called the dissent "larmoyant" and based on "sentinient." Letter from Oliver Wendell Holmes to Sir Frederick Pollock (Mar. 29, 1922), in 2 HOLMES-POLLOCK LETTERS, supra note 105, at 92. 
mean anything more than an encapsulation of the law of attempts. He told Chafee that the expression "clear and present danger"

was not helped by any book that I know of. I think it came without doubt after the later cases (and probably you-I do not remember exactly) had taught me that in the earlier Pat[t]erson case, if that was the name of it, I had taken Blackstone and Parker of Mass. as unrefuted, wrongly. I simply was ignorant. But I did think hard on this matter of attempts in my Common Law and a Mass. case-later in the Swift case (U.S.) - and I thought it out unhelped. ${ }^{241}$

The passage is revealing in several respects. First, while "the later cases" (by which Holmes may have meant the Toledo Newspaper case; ${ }^{242}$ he could not have meant Fox v. Washington ${ }^{243}$ ) might have "taught" Holmes that the First Amendment was not confined to prior restraints, Chafee could surely not have taught him that, smce Holmes was not acquainted with Chafee or his work at the time he wrote Schcnck. ${ }^{244}$ Holmes remembered Chafee as having taught him something, however; possibly, Chafee had taught him that "clear and present danger" had significant doctrinal possibilities and that protection for free speech could be seen as based on "democracy" and "search for truth" as well as "liberty" premises.

Second, when Holmes discussed clear and present danger in the letter, his comments were exclusively about the law of attempts. $\mathrm{He}$ referred to The Common Law, where he had an extensive discussion of attempts; to "a Mass. case" (probably Peaslee, ${ }^{245}$ possibly Kennedy ${ }^{246}$ as well); and to $S$ wift, ${ }^{247}$ all of which were attempt cases. The formulations of the law of attempts he had made in those cases, we have seen, were analogous to "clear and present danger": they einphasized "proximity and degree."248 The last sentence of the passage, with its reference to "it," brought the reader back to "this matter of attempts," as if Holmes still regarded the "clear and present danger" dictum in that context. In short, the letter suggests that Holmes' memory of the origins of the dic-

241. Rabban, Emergence, supra note 12, at $1265-66$ (quoting Letter from Oliver Wendell Holmes to Zechariah Chafee, Jr. (June 12, 1922), in Zechariah Chafee, Jr., Papers (Harvard Law Library)). But see Ragan, supra note 10, at 26 \& $\mathrm{n} .12$ (reading the handwritten letter as saying "Patriotic" rather than "Pat[t]erson").

242. Toledo Newspaper Co. v. United States, 247 U.S. 402 (1918), overruled by Nye v. United States, 313 U.S. 33 (1941).

243. 236 U.S. 273 (1915).

244. There is no indication in Holnes' correspondence that he had been exposed to Chafee's 1918 article on free speech in The New Republic, Chafee, Freedom of Speech, supra note 22, and in any event that article did not discuss the issue of whether the First Amendment was confined to prior restraints.

245. Commonwealth v. Peaslee, 59 N.E. 55 (Mass. 1901).

246. Conumonwealth v. Kennedy, 48 N.E. 770 (Mass. 1897).

247. Swift \& Co. v. United States, 196 U.S. 375 (1905).

248. See supra text acconipanying notes 135-38. 
tum-which for him was firmly set in the law of attempts-was quite distinct from his memory of his subsequent education about First Amendment issues. With respect to that latter memory, he identified Chafee as one of his teachers.

\section{Holmes' Dissent in Abrams: Reformulating "Clear and Present Danger"}

The foregoing analysis of the dialogue between Holmes and his younger contemporaries in the interval between Schenck and Abrams suggests that when Holmes considered Abrams, about a month after Chafee had described the results of their tea that July, he knew exactly what he was doing: he was seeking to reformulate the meaning of "clear and present danger." He used the facts of Abrams to aid him in that task.

In Abrams a group of Russian immigrants had published and distributed leaflets, both im Enghish and in Yiddish, criticizing President Woodrow Wilson's decision to send troops into Russia in support of persons fighting against the Bolshevik government. ${ }^{249}$ The leaflets, apparently directed at factory workers in New York, also urged those workers to engage in a general strike, declaring that they were manufacturing weapons to use against their Russian comrades. ${ }^{250}$ The leaflets were distributed when the United States was still at war against Germany. ${ }^{251}$

The case differed from the Schenck trilogy because the Espionage Act of $1917^{252}$ had been amended by the Sedition Act of 1918. ${ }^{253}$ The Sedition Act made it a crime, when the United States was at war, to "willfully ... urge, incite, or advocate any curtailment of production ... with intent . . . to cripple ... the United States in the prosecution of the war."254 Successful prosecution of the case required that the defendants had a specific intent to interfere with the war against Germany, as distinguished froin the U.S. expedition to Russia. ${ }^{255}$ Moreover, because the indictments rested on the broader language of the 1918 Amendment rather than the original language of the 1917 Act, the Court was required to confront seditious hibel on the face of the Sedition Act. Abrams was undeniably a case in which the government sought to restrict speech itself.

The defendants im Abrams argued both that they lacked the requisite

249. See Abrams v. United States, 250 U.S. 616, 617, $619-20$ (1919).

250. Id. at 621.

251. See id. at 617.

252. Espionage Act of 1917 , ch. 30,40 Stat. 217.

253. Sedition Act of 1918, ch. 75, 40 Stat. 553, repealed by Act of Mar. 3, 1921, ch. 136, 41 Stat. $1359,1360$.

254. Id. $\S 3,40$ Stat. at 553 .

255. Abrams, 250 U.S. at 621 . 
intent to be convicted under the Espionage Act as amended by the Sedition Act and that the entire Act was unconstitutional under the First Amendment. ${ }^{256}$ The majority in Abrams, in an opinion by Justice John Clarke, found the Schenck trilogy dispositive of the First Amendment claim. "Th[e] [defendant's] contention," Clarke asserted, "is sufficiently discussed and is definitely negatived in [Schenck and Frohwerk]."257

Clarke then turned to the question of statutory intent, resurrecting Holmes' language in Debs: a statement that was "part of a general program" of opposition to war could be the basis for finding a specific intent to obstruct a particular war "if, in all the circumstances, that would be its probable effect."258 "Men inust be held to have intended, and to be accountable for," Clarke argued, "the effects which their acts were likely to produce." 259 The "obvious effect" of the leaflets was "defeat of the war program of the Uinited States." 260 The defendants thus had the requisite intent for conviction.

The set of facts presented in Abrams made Holmes' dissent particularly interestimg. Those facts arguably inade the defendants' advocacy inore of a "clear and present danger" to the war effort than any of the speeches dehivered by previous Espionage Act violators. Schenck had dehivered circulars to draftees, but the circulars had only spoken abstractly of the evils of conscription; ${ }^{261}$ Frohwerk had not delivered circulars to anyone, and the pamphlets he printed were not directed specifcally at draftees; ${ }^{262}$ Debs had not said anything specific about draft resistance to World War I. ${ }^{263}$ The defendants in Abrams had printed leaflets and thrown them out the window of a factory, knowing they might be received by inunitions workers, whose factory was in the vicinity. The leaflets urged a general strike, which if undertaken would certainly have hindered the war effort. ${ }^{264}$ Yet Holmes chose Abrams as an opportunity to argue that the First Amendment should be read as placing significant restrictions on the Espionage Act and comparable statutes.

A clue to Holmes' purposes in Abrams can be found in the way in which he described the leaflets that had been distributed. Clarke had set

\footnotetext{
256. Id. at $618-19,621$.

257. Id. at 619.

258. Debs v. United States, 249 U.S. 211, 215 (1919).

259. Abrams, 250 U.S. at 621.

260. Id.

261. See Schenck v. United States, 249 U.S. 47, 49-51 (1919).

262. See Frohwerk v. United States, 249 U.S. 204, 205 (1919).

263. See Debs, 249 U.S. at 213-14.

264. For a thorough account of the Abrams case, see Richard Polenderg, Fighting FAIthS: The Abrams CASE, THE SUPREME COURT, AND FreE SPEECH (1987); see also Zechariah Chafee, Jr., A Contemporary State Trial-The United States Versus Jacob Abrams Et Al., 33 Harv. L. REV. 747, 747-48 (1920). Chafee indicated that the circulars were thrown out of the window in the early morning when a crowd was loitering at a street corner directly below the window. Id. at 747. Many of the crowd were waiting to begin work in a nearby manufacturing building. Id.
} 
forth the language of those leaflets in great detail: in inuch of his opinion, Clarke quoted the leaflets verbatim. ${ }^{265}$ Despite Clarke's thorough treatment, Holmes in his dissent chose to paraphrase the leaflets, and to paraphrase them in a strikingly informal way. After including some of the leaflets' vivid language, inost of it without quotation, ${ }^{266}$ Holmes said that one of the leaflets "goes on,"267 that another "winds up,"268 and ends with "soine usual tall talk."269 Juxtaposing paraphrased sentences froin the leaflets with these informal side comments considerably reduced the incendiary quality of the leaflets: they now appeared as caricatures of early twentieth-century radical prose. This was not accidental, for Holmes subsequently characterized the leaflets as "silly,"270 as "poor and puny anonyımities,"271 and as products of a "creed of ignorance and immaturity."272

Holmes' distinctive recapitulation of the facts of Abrams had a larger purpose. His general effort in the Abrams dissent was to imbue the phrase "clear and present danger," previously a formula akin to that of causation in the law of torts or crimes, with a substantive ineaning: to convert it to a standard of judicial review limiting governmental efforts to suppress speech. In Abrams, the act of throwing leaflets out the window to an audience that contained mumitions workers had come far closer to the objective of bringing those leaflets into the consciousness of those engaged in the war effort than the act, as in Frohwerk, of printing circulars. But "clear and present danger," under Holmes' reformulation, was no longer just a function of how directly the act incited the proscribed objective; it was also a function of how hikely the act would succeed at achieving its objective. Holmes was suggesting in Abrams that the danger of proscribed conduct was diminished by the "silly," "puny," and "immatur[e]" character of the leaflets' inessages. Holmes' recapitulation of the Abrams facts, then, served his purpose of encouraging courts, in applying the "clear and present danger" formula, to consider the hikely effectiveness of the speech sought to be suppressed.

Holmes' dissent served other purposes as well. Among those was a suggestion that where First Amendment rights were implicated, the standard for finding the requisite intent for an offense differed from the common-law standard. The inajority had conceptualized Abrams as principally a case of statutory interpretation rather than constitutional

265. See Abrams, 250 U.S. at 619-23.

266. See id. at 625-26 (Holmes, J., dissenting).

267. Id. at 625 .

268. Id. at 626 .

269. Id.

270. Id. at 628 .

271. Id. at 629.

272. Id. 
law. Clarke had asserted that the First Amendment issue could be summarily disposed of, and therefore the principal issue was whether the defendants had the requisite intent to come under the Espionage Act as amended. ${ }^{273}$ In interpreting the Espionage Act, Holmes found the common-law analogy, which had previously inforned his discussion of First Amendment cases, now inapposite. As he put it:

I am aware ... that the word intent as vaguely used in ordinary legal discussion means no more than knowledge at the time of the act that the consequences said to be mtended will ensue. Even less than that will satisfy the general principle of civil and criminal hability. A man may have to pay damages, may be sent to prison, at common law might be hanged, if at the time of his act he knew facts from which common experience showed that the consequences would follow, whether he individually could foresee them or not. 274

This treatment of intent, Holmes argued in his dissent, should not govern in Abrams. "It seems to ine," he said, "that this statute must be taken to use its words in a strict and accurate sense."275 Any other usage, in his view, "would be absurd."276 Under a strict definition of intent "a deed is not done with intent to produce a consequence unless that consequence is the aim of the deed."277 An actor "does not do the act with intent to produce [the consequence] unless the aim to produce it is the proximate motive of the specific act."278 Holmes concluded that "[t]o say that [speech] might import a suggestion of conduct that would have interference with the war as an indirect and probably undesired effect seems to me by no uneans enough to show an atteinpt to produce that effect."279

Holmes gave no reasons for his abandonment of the analogy to causation in the common law of attempts or for his conclusion that intent in the statute "must be taken" strictly. He had, however, made a distinction between "act[s]" in the common-law exainples and "words" in his discussion of the construction of the statute. Because the First Amendment was implicated, Holmes seeined to be suggesting in this distinction, the statute needed to be imterpreted strictly and the "indirect" test of causation abandoned.

The most significant purpose of Holmes' dissent in Abrams, however, was to advance a reconfiguration of First Amendment doctrine, allegedly based on his dictum $m$ Schenck and anticipated by Chafee. To do so he turned to what he considered "a more important aspect of the

273. See supra text accompanying notes $256-60$ (discussing the majority opinion in Abrams).

274. Abrams, 250 U.S. at 626-27 (Holmes, J., dissenting).

275. Id. at 627 .

276. Id.

277. Id.

278. Id. Compare Model Penal CODE $\S 2.02(2)$ (a) (1962) (definition of "purposely") with id. $\S 2.02(2)(b)$ (definition of "knowingly").

279. Abrams, 250 U.S. at 629 (Holmes, J., dissenting). 
case," the First Amendment issue. ${ }^{280}$ He first reasserted the primacy of the Schenck formula in evaluating First Amendment claims:

I never have seen any reason to doubt that the questions of law that alone were before this Court in the eases of Schenck, Frohwerk, and Debs were rightly decided. I do not doubt for a moment that by the same reasorning that would justify punishing persuasion to murder, the United States constitutionally inay punish speech that produces or is intended to produce a clear and imminent danger that it will bring about forthwith certain substantive evils that the Uinited States constitutionally may seek to prevent. ...

But as against dangers peculiar to war, as agaimst others, the principle of the right to free speech is always the same. It is only the present danger of immediate evil or an intent to bring it about that warrants Congress in setting a limit to the expression of opinion where private rights are not concerned. Congress certainly cannot forbid all effort to change the mind of the country. ${ }^{281}$

In this passage, some of Holmes' alterations of his Schenck dictum were bold; others were sufficiently subtle as to virtually escape notice. Holmes had invoked the Schenck trilogy and had referred to the inurder example in an effort to mamtain consistency and to remind his audience that anyone must concede that free speech must have some limits. But he qualified the constitutional ability of the government to punish speech with the "clear and present danger formula," which was also restated as "imminent danger." What had in Schenck been "substantive evils that Congress has a right to prevent" 282 became in the reformulation "certain substantive evils that the Uinted States constitutionally may seek to prevent."283

These changes were not minor. Since Holmes had not referred to a "clear and present danger" in Frohwerk and Debs, and since he had employed the bad-tendency test in both those cases, ${ }^{284}$ the trilogy of 1919 cases could have been taken sinply as attempt cases, with the "clear and present danger" dictum serving as one of Holnes' vivid aphorisms. In Abrams, however, "clear and present danger" moved to the center of First Amendment analysis: ouly speech that "produces or is intended to produce a clear and imminent danger" could constitutionally be punished.

The position of the government in speech cases had also been altered. Instead of having "a right to prevent" substantive evils, the government was "seek[ing]" to prevent those evils, and only "certain" evils

280. Id. at 627 .

281. Id. at 627-28 (citations omitted).

282. Schenck v. United States, 249 U.S. 47, 52 (1919).

283. Abrams, 250 U.S. at 627 (Holmes, J., dissenting).

284. See supra text accompanying notes 144-61. 
were appropriate-those that the government could "constitutionally prevent." Moreover, the government was now referred to as "the United States," not simply "Congress," so the limitations on restricting speech extended to executive and judicial as well as legislative acts.

Holmes then confirmed in his dissent the substantivc nature of his restated test by saying that "the principle of the right to free speech [was] always the same," even in wartime, and restating the "clear and present danger" fornula. ${ }^{285} \mathrm{He}$ also introduced a qualification that might easily go unnoticed. Once the "clear and present danger" test had been satisfied, Congress could "set[ ] a limit to the expression of opinion [in cases] where private rights are not concerned."286 This intinated that First Amendinent cases involving public inatters were different, perhaps even that the "clear and present danger" test did not apply where the subject of the speech was private. It suggested that First Amendinent protection might be closely linked to the public nature of the speaker's comments. In this observation Holmes was following Chafee, who had described the First Amendment as proinoting "the public discussion of all public questions."287

Having reconfigured the appropriate test in First Amendment cases, Holmes apphed it to the Abrams facts. "Now nobody can suppose," he maintained, "that the surreptitious publishing of a silly leaflet by an unknown man, without inore, would present any immediate danger that its opimions would hinder the success of the government arms or have any appreciable tendency to do so."288 Moreover, once the "strict" defiintion of intent was employed, Holines "[could] not see how anyone can find the intent required by the statute in any of the defendants' words."289 Further, Holmes stated that "there is no hint at resistance to the United States as I construe the phrase."290 In short, "the defendants are to be niade to suffer not for what the indictnient alleges but for the creed that they avow," a creed which "no one has a right even to consider in dealing with the charges before the Court."291

Holmes then addressed what he thought the Abrams case was all about: "[p]ersecution for the expression of opinions." $292 \mathrm{He}$ had written Laski in 1918 that "if you are cocksure, and . . . you have no doubt of your power-you will do what you believe efficient to bring about what you want," but "[i]n most matters of belief we are not cocksure . . . we

285. Abrams, 250 U.S. at 628 (Holmes, J., dissenting).

286. Id.

287. Chafee, Speech in War Time, supra note 22, at 934.

288. Abrams, 250 U.S. at 628 (Holmes, J., dissenting).

289. Id.

290. Id. at 629 .

291. Id. at 629-30.

292. Id. at 630 . 
are not certain of our power."293 In his Abrams dissent he repeated those sentiments:

Persecution for the expression of opinions seems to me perfectly logical. If you have no doubt of your premises or your power and want a certaim result with all your heart you naturally express your wishes im law and sweep away all opposition. To allow opposition by speech seems to imdicate that you think the speech impotent, as when a man says that he has squared the circle, ... or that you doubt either your power or your premises. 294

While this passage seems at first blush to be articulating a rationale for suppressimg speech, its actual purpose was to convey one of Holmes' central philosophical points in Abrams : that where matters of behef were concerned people rarely had "no doubt of [their] premises." $\mathrm{He}$ made that point in the following manner:

But when men have realized that tine has upset many fighting faiths, they may come to behieve even more than they beheve the very foundations of their own conduct that the ultimate good desired is better reached by free trade in ideas-that the best test of truth is the power of the thought to get itself accepted in the competition of the inarket, and that truth is the only ground upon which their wishes safely can be carried out. ${ }^{295}$

In this paragraph one can see the interaction of Holmes' cultural determinism, which had led him in The Common Law to speak of experience overwhelming logic in the law, so that legal theories and legal doctrines inevitably came to reflect "the felt necessities" of the times, ${ }^{296}$ with Chafee's conception of "[t]he true meaning of free speech" as "the discovery and spread of truth on subjects of general concern."297 One could value "free trade in ideas" even more than one valued "the very foundations of [one's] own conduct" because "fighting faiths" were ephemeral and subject to change. Equating "truth" with "the power of the thought to get itself accepted in the competition of the market" captured the inevitable boundaries placed on ideas by current "felt necessities."

Holmes' conception of the "search for truth" was thus quite a different one from that of Chafee and the other progressive theorists who sought to shift the premises of free speech theory in the early twentieth century. For Chafee and those who emphasized the social interest in free speech, the search for truth was part of a process in which public opinion could become more inforined and enlightened. For Holmes, "truth" was

293. Letter from Oliver Wendell Holmes to Harold J. Laski (July 7, 1918), in 1 HoLMES-LASKI LETTERS, supra note 1, at 160-61.

294. Abrams, 250 U.S. at 630 (Holmes, J., dissenting).

295. Id.

296. HOLMES, supra note 134, at 1.

297. Chafee, Speech in War Time, supra note 22, at 956. 
the equivalent of majoritarian prejudice at any point in time. He defined it to Laski as "the prevailing can't help of the majority,"298 and to Learned Hand as "the majority vote of that nation that can lick all others."299 The optimistic, democratic vision of Chafee and his progressive contemporaries had resonated with Holmes' skeptical resignation about the primacy of majoritarian sentiment. The "search for truth" metaphor, embodying both of those perspectives, had arrived in American free speech jurisprudence.

Holmes then emphasized the constitutional significance of the "search for truth" metaphor. Immediately after associating "the ultimate good" with a "free trade in ideas" designed to search for truth, he aimounced:

That at any rate is the theory of our Constitution. It is an experiment, as all life is an experiment. Every year if not every day we have to wager our salvation upon some prophecy based upon imperfect knowledge. While that experiment is part of our system I think that we should be eternally vigilant against attempts to check the expression of opinions that we loathe and beheve to be fraught with death, unless they so imminently threaten immediate imterference with the lawful and pressing purposes of the law that an immediate check is required to save the country. ... Only the emergency that makes it immediately dangerous to leave the correction of evil counsels to time warrants making any exception to the sweeping command, "Congress shall make no law ... . abridging the freedom of speech." 300

In this passage Holmes explicitly hinked the "clear and present danger" test to the idea that thoughts gained or lost acceptance in "the market" of ideas and were "corrected" with time, producing "truth," an idea now characterized as "the theory of our Constitution." Somehow the "experimental" character of the constitutional scheme of government was linked to the "experimental" process by which ideas were tested and discarded in the marketplace. And since "the ultimate good" was reached by allowing this experimental process to go on, only those ideas that directly threatened the existence of the nation should be removed from the process by being suppressed. The First Amendment had become a "sweeping command" that directed all ideas to the marketplace unless they immediately threatened the country.

Needless to say, after Holmes' reformulation in Abrams, his conception of the First Amendment generally, and of the "clear and present danger" test in particular, bore little resemblance to their counterparts in

298. Letter from Oliver Wendell Holmes to Harold J. Laski (Jan. 11, 1929), in 2 HoLmesLASKI LETTERS, supra note 1, at 1124.

299. Letter from Oliver Wendell Holmes to Learned Hand (June 24, 1918), in Holmes Papers, supra note 13 (referring to the view of truth he had when he was young).

300. Abrams, 250 U.S. at 630-31 (Holmes, J., dissenting). 
the 1919 Espionage Act cases. In Holmes' original treatment of the First Amendment issues in those cases, notwithstanding the clear-and-presentdanger dictum, the presence of a First Amendment claim added nothing to an analysis that conceptualized the cases as attempt cases. ${ }^{301}$ Clarke's inajority opimion in Abrams, in fact, had been faithful to the Schenck trilogy in its summary treatinent of the defendants' First Amendment argument. It was Holmes who sought to change the rules.

Reaction to Holmes' dissent in Abrams, from the same sources that had initiated commumication with him on First Amendment issues, was swift and, from Holmes' point of view, must have been eminently satisfactory. Laski wrote that "amongst the many opinions of yours I have read, none seens to me superior either in nobility or outlook, in dignity or phrasing, and in that quality the French call justesse."302 Felix Frankfurter wrote of "the gratitude and ... the pride I have in your dissent," adding that "[y]ou speak there as you have always spoken," but "this tinie we need education in the obvious." wrote an editorial, The Call to Toleration, featuring Holmes' dissent, ${ }^{304}$ and commissioned an article highly critical of the majority opinion. ${ }^{305}$ And Chafee devoted a law-review article to the case in which he referred to "Justice Holmes's inagnificent exposition of the philosophic basis" of the First Amendinent. ${ }^{306}$ Chafee asserted that the effect of the majority decision "should be temporary in view of ... the enduring qualities of the reasoning of Justice Holmes" 307 and concluded that "[o]n the constitutional point, hittle can be added to the statement of Justice Holmes." Chafee beheved that Holmes' dissent 'must carry great weight as an interpretation of the First Amendment, because it is only an elaboration of the principle laid down by him with the backing of a unanimous court in Schenck v. United States." 309 The "clear and present danger" test as reforinulated, Chafee concluded, could now be taken as "marking the true limit of governmental interference with speech and writing under our constitutions." 310 The first stage in the modernization of free speech

301. See supra text accompanying notes 140-61.

302. Letter from Harold J. Laski to Oliver Wendell Holmes (Nov. 12, 1919), in 1 HoLMESLASK1 LETTERS, supra note 1, at 220.

303. Letter from Felix Frankfurter to Oliver Wendell Holmes (Nov. 12, 1919), in Holmes Papers, supra note 13.

304. The Call to Toleration, New RePublic, Nov. 26, 1919, at 360 (editorial).

305. See Gerard C. Henderson, What Is Left of Free Speech, NEw RePubL1C, Dec. 10, 1919, at 50.

306. Chafee, supra note 264 , at 769.

307. Id. at 771 .

308. Id. at 769 .

309. Id.

310. Id. at 771. Of those who had participated in the conversations with Holmes about free speech only Learned Hand continued to express reservations, although Chafee privately concurred in some of Hand's concerns. Hand felt that the "clear and present danger" test gave too much 
jurisprudence had been completed.

\section{Holmes' Later Free Speech Opinions: Consciousness Overrides Consistency}

Abrams, the case in which Holmes decisively abandoned earlier orthodoxy and embraced a conception of the First Amendment that encompassed substantive limitations on governmental power, has rightly been identified as "the constitutional divide" in the evolution of his views on free speech. ${ }^{311}$ In his post-Abrams free speech opimons Holmes regularly adopted speech-protective positions and thereby cemented his reputation among commentators as a libertarian on free speech issues. Surprisingly little attention, however, has been paid to the language of those opinions, which is not easily reconcilable with Holmes' language in Abrams. ${ }^{312}$

There is no question that Holmes' later speech decisions reflected his expanded consciousness of the First and Fourteenth Amendments, which treated them as constitutional provisions with significant substantive bite, as distinguished from mere codifications of, or analogies to, the common law. The shape of Holmes' consciousness in the later free speech cases, however, was essentially idiosyncratic. While he continued to adhere, reflexively, to the "clear and present danger" test, he went well beyond it in some imstances, apparently adopting an ultralibertarian posture. Further, while Holmes began to conceptualize some types of cases as raising free speech concerns when he had not previously done so, he sinultaneously contmued to resist any effort to treat speech as an essential liberty, akin to liberty of contract. As he neared the end of his tenure, Holmes seemed far more concerned with exhibiting his enhanced sensitivity to the free speech iniplication of cases than with maintaiming doctrinal consistency with his earher decisions. In his attempts to exhibit a sensitivity to free speech issues Holmes provided some clues about his essential orientation as a First Amendment theorist and as a judge.

In the first set of free speech cases decided after Abrams, Holmes continued to exhibit the enhanced consciousness he had demonstrated in that case. In the 1920 Term he joined two Brandeis dissents from majority opinions that apphied the bad-tendency test and treated intent generally under the Espionage Act. In his dissenting opinions, Brandeis

leeway to juries to define the limits of protection for speech in an impressionistic fashion. See Gunther, supra note 10, at 749 (quoting Letter from Learned Hand to Zechariah Chafee, Jr. (Jan. 2, 1921), in Zechariah Chafee, Jr., Papers (Harvard Law Library)).

311. Rabban, Emergence, supra note 12, at 1317.

312. In 1941, Zechariah Chafee wrote of the Schenck-Abrams sequence: "Looking backward ... we see that Justice Holmes was biding his time until the Court should have before it a conviction so clearly wrong as to let him speak out his deepest thoughts about the First Amendment." CHAFEe, supra note 112 , at 86 . 
reiterated that the "clear and present danger" test should control judicial assessinents of subversive speech ${ }^{313}$ and that a specific intent to engage in prohibited activity should be required to sustain a conviction where speech rights were at stake. ${ }^{314}$ In the 1921 Term, Holmes dissented separately froin Brandeis in United States ex rel. Milwaukee Social Democratic Publishing Co. v. Burleson. ${ }^{315}$

In Burleson the Postmaster General denied second-class inailing privileges to the Milwaukee Leader on the ground that the paper had printed articles critical of the war effort and was, therefore, a "non-niailable" publication within the ineaning of the 1917 Espionage Act. ${ }^{316}$ Although the Act did not address whether future issues of a "non-1nailable" publication could be barred, the Postınaster General argued that because past violations had resulted in the newspaper's forfeiting its second-class inailing privileges, the government could declime to renew them. ${ }^{317}$ The niajority held that the articles clearly violated the Espionage Act and that the Postinaster General could presume that future publications would also violate the Act. Brandeis wrote an elaborate dissent, arguimg that the Postmaster General had no discretionary authority to exclude publications from the inails based on a guess as to their future content. ${ }^{318}$ Holmes dissented separately. He confessed that, until he had read Brandeis' dissent, he had been inclimed to support the majority's position on the ground that "if a publisher should announce in terms that he proposed to primt treason and should deniand a second-class rate it inust be that the Postmaster General would have authority to refuse it." 319 But Holmes had becoine convinced that "[t]he question of the rate has nothing to do with the question whether the niatter is niailable," and that the Postmaster General could not determine nonniailability in advance. $^{320}$ The ouly thing the Postniaster General was einpowered to do under the statute, Holmes felt, was to deny second-class inail privileges, and after the pubhications were inailed "to refrain fron forwarding the papers . . . and to return thein to the senders." $321 \mathrm{He}$ was not enipowered to decide, on the basis of a publication's content, that it could not be carried in the mails. ${ }^{322}$

Holmes argued that the Postınaster General lacked authority to absolutely deny access to the mails in the future absent explicit language

313. Schaefer v. United States, 251 U.S. 466, 482-83 (1920) (Brandeis, J., dissenting).

314. Pierce v. United States, 252 U.S. 239, $271-72$ (1920) (Brandeis, J., dissenting).

315. 255 U.S. 407, 436 (1921) (Holınes, J., dissenting).

316. 255 U.S. at $410-12$.

317. Id. at 412 .

318. Id. at 417 (Brandeis, J., dissenting).

319. Id. at 436-37 (Holnes, J., dissenting).

320. Id. at 437.

321. Id.

322. Id. 
conveying that authority. ${ }^{323}$ So long as the United States maintained a Post Office, he suggested, "the use of the mails is almost as much a part of free speech as the right to use our tongues, and it would take very strong language to convince me that Congress ever intended to give such a practically despotic power to any one man." 324 Otherwise, the power claimed for the Postmaster General "could be used to interfere with very sacred rights." 325 According to Holmes, denial of second-class mailing privileges for the future was "a serious attack upon liberties."326

Holmes' response to the free speech implications of Burleson was in stark contrast to his treatment of arguably similar cases earlier in his career. Holmes had conceded that " $[t]$ he United States may give up the Post Office when it sees fit." ${ }^{327} \mathrm{He}$ did'not accept the government's argument, however, that "a citizen uses the mail at second-class rates not as of right- but by virtue of a privilege or permission, the granting of which rests in the discretion of the Postmaster General."328 In fact, Holmes spoke in his opinion of "rights" and "hiberties" in the use of the mails. ${ }^{329}$ Yet in his previously cited opinion in McAuliffe v. Mayor of New Bedford, ${ }^{330}$ the Massachusetts case involving a policeman who was fired for engaging in partisan political activity, he had summarily dismissed a First Amendment claim that the government could not condition access to its employment on conformity to its rules where those rules included a ban on the expression of political sentinients. ${ }^{331}$ Burleson embodied an analogous claim - that the government could condition access to its mailing privileges, which it could withdraw at any point, on a user's not engaging in seditious speecli. And yet Holmes, who had announced that there was no constitutional right to be a policeman, suggested in Burleson that there was a constitutional right to use the inails. His shift of position was consonant witl the enhanced sensitivity to free speech issues that his Abrams dissent had demonstrated. ${ }^{332}$

After Burleson, in the 1922 Term, Holmes wrote opinions in two

323. See id.

324. Id.

325. Id. at 438 .

326. Id.

327. Id. at 437.

328. Id. at 427 (Brandeis, J., dissenting).

329. See id. at 437-38 (Holmes, J., dissenting).

330. 29 N.E. 517 (Mass. 1892).

331. Id. at 517.

332. For another case demonstrating Holmes' enhanced sensitivity to free speech issues, see Leach v. Carlile, 258 U.S. 138, 140 (1922) (Holmes, J., dissenting). In Leach, Holmes found a First Amendment violation in the Postmaster General's refusal to deliver mail to a company that had advertised "Organo Tablets," which it manufactured as a general cure for illness, an advertisement that the Postmaster considered fraudulent. 258 U.S. at 139. "If the execution of this law does not abridge freedom of speech," Holmes wrote, "I do not quite see what could be said to do so." Id. at 141 (Holmes, J., dissenting). 
cases that at first blush appear to bear no relationship to his free speech jurisprudence, but on closer analysis prove to comphicate the nature of his newfound solicitude for speech rights. The two cases tested the constitutionality of efforts by three states to restrict the teaching of foreign languages in their public schools. The first case, Meyer v. Nebraska, ${ }^{333}$ involved a Nebraska statute forbidding the teaching of any langnage other than Enghish before the eighth grade. The second case, Bartels $v$. Iowa, ${ }^{334}$ consolidated four challenges to similar statutes in Iowa, Ohio, and Nebraska that prohibited the teaching of all languages except Enghish before the eighth grade or prohibited the teaching of German before the eighth grade. A inajority of the Court conceptualized the cases as raising liberty issues under the Fourteenth Amendinent's Due Process Clause and invalidated all the statutes. Justice McReynolds, writing for the Court, gave a list of the sorts of activities encompassed within the term "liberty":

Without doubt, it denotes not merely freedom from bodily restraint but also the right of the individual to contract, to engage in any of the common occupations of life, to acquire useful knowledge, to marry, establish a home and bring up children, to worship God according to the dictates of his own conscience, and generally to enjoy those privileges long recognized at common law as essential to the orderly pursuit of happiness by free men. ${ }^{335}$

McReynolds' conceptualization echoed the liberty arguments advanced by late nineteenth-century commentators, who had assumed that liberty in the Due Process Clause of the Fourteenth Amendinent theoretically extended well beyond its familiar contract and property contexts. By the 1922 Term, however, no case had yet held that First Amendinent protections were incorporated within the Fourteenth Amendment's Due Process Clause and thereby applicable against the states. Even McReynolds' cataloging of liberties to worship God or to acquire useful knowledge, while closely associated with the First Amendment's protection of speech or the free exercise of rehioion, did not rest on any incorporation arguments. McReynolds' hist of protected liberties did suggest, however, that he viewed the logic of the Court's substantive due process decisions as liad earher commentators; nainely, as leading to the eventual judicial designation of speech as a hiberty within the ineaning of the Fourteenth Amendinent.

Having characterized the foreign langnages cases as hiberty cases, McReynolds proceeded through the familiar substantive due process analysis that had been einployed by late nineteenth- and early twentieth-

333. 262 U.S. 390 (1923).

334. 262 U.S. 404 (1923).

335. Meyer, 262 U.S. at 399. 
century courts in "liberty of contract" cases. That analysis was premised on the assumption that "liberty may not be interfered with, under the guise of protecting the public interest, by legislative action which is arbitrary or without reasonable relation to some purpose within the competency of the State to effect."336 McReynolds concluded that the statutes restricting the teaching of foreign languages bore no reasonable relation to any end within the competency of the state. ${ }^{337}$ One stated end of the legislation, he noted, was fostering civic pride and a homogeneity of ideals. ${ }^{338}$ But given that ancient languages were exempt from the prohibition in Nebraska, and that the German language was singled out in Ohio, he concluded that the means adopted in furtherance of that end were too intrusive. ${ }^{339} \mathrm{McReynolds}$ intimated that "[u]nfortunate experiences during the late war and aversion toward every characteristic of truculent adversaries" may have precipitated the statutes. ${ }^{340}$ He disinissed out of hand the claim that the legislation was intended to "protect the child's health by limiting his mental activities," pointing out that proficiency in a foreign language was associated with early exposure to it and that no evidence had suggested such exposure had deleterious health effects. ${ }^{341}$

Holmes dissented in all the cases except those in which the German language alone had been singled out for prohibition. His dissent was based on the proposition that "[w]e all agree . . . that it is desirable that all the citizens of the United States should speak a common tongue, and therefore that the end aimed at by the statute is a lawful and proper one."342 The logic of that proposition is hard to follow. One might assume that a state has an interest im promoting the common language of the nation and offering that language, whether or not it offers other languages, in its public schools. But would that interest bear a reasonable and fair relationship to state requirements precluding its citizens from speaking other languages? The statutes at issue in Meyer and Bartels did not merely establish Enghish as the common language of public education by ratifying the practice of not offering courses in other languages; they also prohibited the teaching of language courses that had previously been offered. Moreover, they prohibited only soine languages, not including in their prohibitions ancient languages or, in the Ohio statute, all other languages except German. The states thus appeared less concerned with promoting a common tongue than in preventing their citizens froin access to certain undesirable tongues.

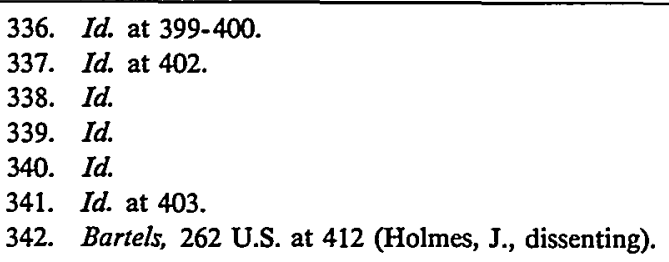


Holmes' dissent, however, assumed that if the purpose of the statute was arguably reasonable, the means by which that purpose was implemented were also reasonable, except where one foreign language was singled out for prohibition. He asserted:

Youth is the time when familiarity with a language is established and if there are sections in the State where a child would hear ouly Pohish or French or German spoken at home I am not prepared to say that it is unreasonable to provide that in his early years he shall hear and speak only English at school. ${ }^{343}$

And if a statute prohibitimg the teaching of all foreign languages was reasonable, Holmes argued,

it is not an undue restriction of the liberty either of teacher or scholar. No one would doubt that a teacher might be forbidden to teach many things, and the only criterion of his liberty under the Constitution that I can think of is "whether, considering the end in view, the statute passes the bounds of reason and assumes the character of a merely arbitrary fiat."344

These comments were striking, especially in light of the time during which Holmes wrote them. Meyer and Bartels were decided three terms after his Abrams dissent, but Holmes did not treat the claim that the statutes restricted "the hiberty either of teacher or scholar" as precipitating an inquiry comparable to that which would take place in speech cases. Instead he treated the inquiry as comparable to that in "liberty of contract" cases, in which he asked only that legislation purportedly infrimging on economic liberties be rational as distinguished from arbitrary. The language cases did not elicit in Holmes the kind of enhanced scrutiny of legislative efforts that amounted to "[p]ersecution for the expression of opimions." 345

There are two possible explanations for Holmes' failure to sweep the language cases under his new calculus on speech issues. First, he may not have seen thein as primarily raising speech issues, in the same fashion that late nineteenth-century commentators had subsumed the right to advocate the tactic of striking in labor disputes in the economic right to strike. Teaching a foreign language, in this vein, could have been regarded as an occupation rather than as a form of expression. This explanation ignores, however, Holmes' behef that the liberty purportedly being restricted by the statutes was that of a "teacher or scholar." By "scholars" Holmes inust have ineant students in the public schools who sought access to information about the languages of other nations, allegedly to improve their ability to participate in world affairs. This interest in access to information would seem to be closely linked to the interest in

343. Id.

344. Id. (quoting Purity Extract \& Tonic Co. v. Lynch, 226 U.S. 192, 204 (1912)).

345. Abrams v. United States, 250 U.S. 616, 630 (1919) (Holmes, J., dissenting). 
access to diverse views Holmes had identified as part of the "search for truth" in Abrams. It is unlikely, therefore, that Holmes failed to recognize the speech dimensions of the language cases, especially in light of his increased tendency to recognize these dimensions in other cases after Abrams.

A second, more likely, explanation is that the conceptual posture of the language cases made Holmes focus on protection for speech as premised on liberty, as distmguished from speech as premised on the social interest in searching for truth in a democracy. By imterpreting the word "liberty" im the Fourteenth Amendment to mclude noneconomic as well as economic activities, McReynolds' opimion in the foreign language cases imtroduced, for Holines, the jurisprudence of liberty of contract. Holmes reflexively responded by adopting his habitual posture in liberty of contract cases, im which he believed state "experiments" were being subjected to unjustifiable judicial attack on the basis of vague interpretations of the Due Process Clause. ${ }^{346}$ While it was not difficult to see the cases as involving the right of teachers to speak on subjects in which they were proficient, and the right of their students to listen to speech about these subjects, Holmes associated the "liberty ... of teacher or scholar" 347 with the "liberty of contract" context.

That "speech," despite his langnage in Abrams, had not fully broken free in Holmes' mind froin "liberty of contract" analysis is suggested by a comment he inade to Laski in April 1923, before the Meyer and Bartels cases were decided. ${ }^{348}$ In discussing his dissent in the case of Adkins $v$. Children's Hospital, ${ }^{349}$ in whicl the inajority had adopted a "liberty of contract" analysis, Holmes added, "I ain curious to see what the enthusiasts for liberty of contract will say witl regard to liberty of speech under a State law pumshing advocatimg the overthrow of government-by violence. The case was argned this week." 350 The case was Gitlow v. New York, $^{351}$ which was to be reargned and not decided until 1925; it was to produce one of Holmes' inajor free speech opmions.

The implication of Holines' cominent to Laski was that "liberty of speech" would pose a dilemina for those who thought that "liberty of contract" should be broadly applied, smce a coinparable analysis might

346. Because the question of whether promoting "a common tongue" by prohibiting language instruction up to a certain age in the public schools was one "upon whieh men reasonably might differ," Holmes concluded he was "unable to say that the Constitution of the United States prevents the experiment [from] being tried." Bartels, 262 U.S. at 412 (Holmes, J., dissenting).

347. Id.

348. See Letter from Oliver Wendell Holmes to Harold J. Laski (Apr. 14, 1923), in HolmesLASKI LETTERS, supra note 1, at 495.

349. 261 U.S. 525 (1923), overruled by West Coast Hotel Co. v. Parrish, 300 U.S. 379 (1937).

350. Letter from Oliver Wendell Holmes to Harold J. Laski (Apr. 14, 1923), in Holmes-LASKI LETTERS, supra note 1 , at 495.

351. 268 U.S. 652 (1925). 
protect those who advocated subversive activity. The comment presupposed that "liberty of speech" remained a gloss on the Fourteenth Amendment's Due Process Clause, since the incorporation of First Amendment rights in that clause was still in an inchoate state in 1923. Incorporation was to take place in the Gitlow dissent, and Holmes' response to the incorporation argument was to be a revealing one.

Incorporation, however, was not the major issue that Gitlow raised for Holmes. By the time Gitlow was decided it had become apparent that he and other adherents of the "clear and present danger" test faced a dilemma. That test had been designed to deal with situations in which a legislature had identified a proscribed end, such as obstructing the war effort, and the question under the test was whether a particular expression was closely enough related to that end to come within the proscription. In Gitlow, however, the statute had criminalized the form of expression itself. A 1902 New York statute had provided criminal penalties for those who advocated "that organized government should be overthrown by force, or violence or any unlawful means." "352 The statute, originally passed in response to the emergence of anarchism, was apphed against the publisher of The Left Wing Manifesto, a document that paraphrased The Communist Manifesto, calling for class struggle and "revolutionary mass action" " toward the " 'annihilation of the parliamentary state." "353 The only specific action the Manifesto urged, however, was a series of "mass pohtical strikes."354 A inajority of the Court in Gitlow, holding the statute constitutional, conceded that "[t]here was no evidence of any effect resulting from the publication and circulation of the Manifesto."355 That lack of evidence, lowever, was argnably immaterial because the New York Legislature, rather than proscribing action, had proscribed advocacy itself.

The majority lield that given tlie language of the statute, the "clear and present danger" test was inapplicable, so the absence of any causal connection between the defendant's publication and any illegal activity did not matter. Justice Edward Sanford, writing for the majority, reasoned as follows:

It is clear that the question in such cases is entirely different from that involved in those cases where the statute inerely prohibits certain acts involving the danger of substantive evil, without any reference to language itself ... . [In the latter cases the "clear and present danger" test of Schenck governs.] . . . [That test] was manifestly intended . . . to apply only in [the latter] cases, and has no application to those like the present, where the legislative body itself has previously determined the

352. Id. at 654-55 (quoting N.Y. PENAL LAW $\S 161$ (Matthew Bender 1909)).

353. Id. at $658-59$ (quoting THE LEFT WING MANIFESTO).

354. Id. at 659 .

355. Id. at 656 . 
danger of substantive evil arising from utterances of a specified character. $^{356}$

Sanford's analysis assumed that the only question for the Court was whether The Left Wing Manifesto had advocated the doctrine "that organized government shonld be overthrown by force, or violence or any unlawful means." He concluded, for the majority, that it had. He conceded that "[t]he statute does not penalize the utterance or publication of abstract 'doctrine' or academic discussion having no quality of incitement to any concrete action."357 He found, however, that The Left Wing Manifesto "advocates and urges in fervent language mass action which shall progressively foment industrial disturbances and through political mass strikes and revolutionary mass action overthrow and destroy organized parhamentary government."358 It was immaterial to the majority that no effect had followed from the distribution of the Manifesto or that its authors had given no timie frame for the "revolutionary mass overthrow" they urged.

Holmes, joined by Brandeis, dissented in Gitlow. He first took up the incorporation issue, which had been argued by both sides. ${ }^{359}$ The majority had summarily concluded that the First Amendinent was incorporated against the states through the Fourteenth Amendment. Sanford stated that "[f]or present purposes we may and do assume that freedom of speech and of the press ... are among the fundamental personal rights and 'liberties' protected by the Due Process Clause of the Fourteenth Amendment from impairment by the States."360 Holmes, perhaps mindful that lie had addressed and not resolved the incorporation issue in Patterson v. Colorado ex rel. Attorney General, ${ }^{361}$ engaged in a fuller discussion of the issue in his Gitlow dissent, agreeing with the majority. "The general principle of free speech," lie argued, "must be taken to be mcluded in the Fourteenth Amendment, in view of the scope that has been given to tlie word 'liberty' as there used."362 This echoed the comment he had made to Laski in the 1923 letter, when Gitlow was first argued, equating liberty of speech and hiberty of contract. ${ }^{363}$ Holmes' point was that the Court's own extensions of the liberty language in the Fourteenth Amendinent to protect rights in the econoinic arena would make it anomalous not to make the same extension where free speech was imvolved.

\footnotetext{
356. Id. at 670-71.

357. Id. at 664 .

358. Id. at 665 .

359. Id. at 672 (Holmes, J., dissenting).

360. 268 U.S. at 666 .

361. 205 U.S. 454 (1907); see supra text accompanying notes 36-45.

362. Gitlow, 268 U.S. at 672 (Holmes, J., dissenting).

363. See supra text accompanying notes 348-51.
} 
Holmes, however, had protested against the extensions of economic liberties and, in the foreign langnage cases, had resisted treating tiberty of speech as bearing any more constitutional weight than hiberty of contract. He thus added a cryptic sentence to the discussion of incorporation in his dissent. "[P]erhaps," he said, the apphication of the First Amendment against the states "may be accepted with a somewhat larger latitude of interpretation than is allowed to Congress by the sweeping language that governs or ought to govern the laws of the Uuited States." 364

Unraveling that sentence and the one following it reveals the idiosyncratic frame of reference that Holines had come to adopt in free speech cases. In the first sentence, he expressed a reluctance, on the one hand, to endorse incorporation if it were premised on a substantive reading of liberty that might, in the guise of protection for speech, reinforce an expansive reading of economic liberties. Thus, according to Holnes, postincorporation jurisprudence ought to have "a soinewhat larger latitude" to restrict speech rights in order to preserve a comparable latitude to restrict economic rights. On the other hand, he seemed eager to restate his new view of the First Amendment as "sweeping language" severely restricting Congress' powers, the view which he had articulated in Abrams and, as his "ought to govern" language indicated, had not been endorsed by the Court as a whole.

The next sentence, however, muddied things considerably. Holmes said, "If I a1n right, then I think that the criterion sanctioned by the full Court in Schenck v. United States applies" and quoted the "clear and present danger" dictum. ${ }^{365}$ The relationship between the sentences is hard to fathoin. "If I am right" would seein to refer to Holmes' discussion of the incorporation of the First Amendment against the states, the only issue he had thus far discussed in his Gitlow dissent. It could conceivably have referred, more particularly, to his view that free speech restrictions on the states ought perhaps to be less severe than those on the federal governinent. But in either case the application of "clear and present danger" to Gitlow seened to come out of the blue. If the states had more latitude to restrict speech than the federal governinent, judicial tests developed in cases in which Congress had restricted speech might not necessarily be applicable. On the other hand, if Schenck controlled, and the "clear and present danger" test was a rule of causation-evaluating the closeness of the connection between advocacy and illegal actscausation would seein to have been satisfied in those instances in which a legislature had outlawed advocacy itself. It was only if "clear and present danger" in its reformulated version-the version that Holmes insisted

364. Gitlow, 268 U.S. at 672 (Holmes, J., dissenting).

365. Id. (citation omitted). 
had been departed from in Abrams and Schaefer - was the correct test, as Holmes asserted, that the legislative action in Gitlow deserved searching scrutiny. But that would mean that in Holmes' view, incorporated speech cases imvolving actions by the states were to be treated the saine as cases mvolving actions by Congress.

Nonetheless, Holmes proceeded as if the "clear and present danger" test apphied, and concluded that "it is manifest that there was no present danger of an attempt to overthrow the government by force on the part of the admittedly small minority who shared the defendant's views."366 If the publication of the Manifesto had been claimed to have been "an atteinpt to induce an uprising against government at once and not at sone indefinite time in the future," Holmes argued, "it would have presented a different question."367 That would have been a situation "with which the law might deal," he surmised, "subject to the doubt whether there was any danger that the publication could produce any result, or im other words, whether it was not futile and too remote from possible consequences."368

This argument was a familiar one after Abrams. Holmes had come to see the "clear and present danger" test as a substantive evaluation of the seriousness of any threat posed by the speech at issue, even though he couched that inquiry in the "remoteness" language of causation. A speech, under this view, could pose no "clear and present danger," even if it was quite specific in its aims, if its own ineptitude or other circumstances suggested that it would not be taken seriously. A six-year-old's exhortation to other children of the same age to "take up arms against the President right now!' might not qualify under that analysis as a "clear and present danger." "Eloquence may set fire to reason," Holmes said, "[b]ut whatever may be thought of the redundant discourse before us it had no chance of starting a present conflagration."369

Intertwimed with this familiar language, however, was some that, if taken seriously, suggested that Holnues was embarking on yet another stage in his consideration of speech issues, one that might niove him to adopt an ultralibertarian view of speech rights. The majority in Gitlow, after quoting passages from the Manifesto, had stated, "This is not the expression of philosophical abstraction ... ; it is the language of direct incitement."370 Holmes responded:

It is said that this manifesto was more than a theory, that it was an incitement. Every idea is an incitement. It offers itself for belief and if believed it is acted on unless some other belief outweighs it or some failure of

366. Id. at 673 .

367. Id.

368. Id.

369. Id.

370. 268 U.S. at 665 . 
energy stifies the movement at its birth. The only difference between the expression of an opinion and an inciteinent in the narrower sense is the speaker's enthusiasm for the result. ${ }^{371}$

Although this has been a regularly quoted passage, its implications for First Amendment analysis are somewhat obscure. Given Holmes' stated position that normative ideas become "imcitements" or "opinions" if presented with "enthusiasm," and that the "ultimate good" is best served by "free trade in ideas," it would seem that "incitements" should be allowed to "offer [themselves] for behef" and be acted upon if accepted. Under this reasoning, statements urging others to overthrow the government at the conclusion of the speaker's remarks should be given their chance to coine into the market. In breaking down distimctions between ideas, opinions, and incitements, Holmes appeared to adopt an ultralibertarian view of speech.

Such an interpretation of Holmes' "incitement" paragraph in Gitlow is supported by another famous sentence in his dissent. "If in the long run," he wrote, "the beliefs expressed in proletarian dictatorship are destined to be accepted by the dominant forces of the cominumity, the only meaning of free speecli is that tliey should be given their chance and have their way."372

Although at first glance the sentence appears to be another version of Holmes' "free trade in ideas" approach, it contains some ambiguities. His language about "the dominant forces of the cominumity" and his stateinent that "the only meaning of free speech" is that any stated behef should "be given [its] chance" suggest that he regarded any restrictions on free speech as ultimately fruitless. If the choices of the doininant forces of a cominumity are the mechamism by which ideas becoine accepted, certain ideas will "have their way" regardless of their content. In choosing some of these ideas, however, the dominant forces are implicitly rejecting other ideas; indeed, those forces might even decide to bar soine ideas froin the marketplace altogether. Thus, in the passage Holines seems on the one hand to be advancing a view of speech in which the marketplace of ideas determines whicli speech is favored and which is not, and on the other hand endorsing a positivist theory of the relationship between speech and the "dominant forces" of a community. It is not clear, from his language in Gitlow, whether the "only meaming of free speech" has become equated with the opportunity for all ideas to have a chance to "have their way" or has become equated with the prevailing attitudes of "the dominant forces of tlie community."

The dizzyingly contradictory implications of these several sentences in Holmes' dissent in Gitlow should suggest that one runs a risk in read-

371. Id. at 673 (Holmes, J., dissenting).

372. Id. 
ing too considered an ideology into Holmesian language. Holmes was often driven in his opinions by his attraction for language itself. Such phrases as "every idea is an inciteinent" and "the only meaning of free speech" were characteristic of his style. Although the phrases are more arresting and inemorable because of their unqualified language, they consequently collapse as analytical guidelmes.

Moreover, Holmes could not have been expected to be governed by this unqualified language because he beheved that all legal questions were questions of degree. He was very unlikely, despite having said that every idea is an incitement, to abandon the distinction between ideas that ainounted to incitements and those that did not. Accordingly, Holmes was comfortable being governed by his "clear and present danger" dictuin because that test was one of degree and because it invited hin to inake a distinction between inciteinents and other types of speech. Indeed, the phrase "every idea is an incitement" might have been his way of inaking it clear to Learned Hand and his other young friends that he was not about to jettison the "clear and present danger" test for Hand's incitement test in Masses Publishing Co. v. Patten. ${ }^{373}$ For the foregoing reasons, Holmes' Gitlow dissent is better characterized as an exainple of Holmes' distinctive consciousness as a judge than as an attempt to forge a new path in First Amendment jurisprudence after Abrams.

Even if Gitlow did not necessarily signify a inore libertarian posture for Holmes in speech cases, there is abundant evidence revealing his commitment, in the last years of his career, to a point of view irreconcilable with the one he took in the Espionage Act cases. The best evidence of that commitinent comes not froin Gitlow but rather froin Holmes' joining a series of cases, between 1925 and the end of his tenure, which protected free speech claims under a variety of theories, soine of which were inore protectionist than the "clear and present danger" test. These included Brandeis' concurrence in Whitney v. California, ${ }^{374}$ which attacked the Gitlow approach by arguing that the First Amendment did not permit deference to legislatures on the evil of language itself and by seeking to link prohibition of speech directly to incitements; ${ }^{375}$ the decision in Stromberg v. California, ${ }^{376}$ which declared a California statute comparable to the one sustained in Gitlow unconstitutional as applied to the display of a red flag at a political demonstration; and the decision in

373. 244 F. 535 (S.D.N.Y.), rev'd, 246 F. 24 (2d Cir. 1917). In Masses, Hand stated, "If one stops short of urging upon others that it is their duty or their interest to resist the law, it seems to me one should not be held to have attempted to cause its violation." Id. at 540.

374. 274 U.S. 357, 372-80 (1927) (Brandeis, J., concurring) (constitutional challenge to state criminal-syndicalism law), overruled by Brandenburg v. Ohio, 395 U.S. 444 (1969).

375. Id. at $373,374,376$.

376. 283 U.S. 359 (1931). 
Near v. Minnesota ex rel. Olson, ${ }^{377}$ which invalidated as a prior restraint a Minnesota statute that permitted the enjoining of "malicious, scandalous, or defainatory" publications. In only one free speech case after Abrams did Holmes fail to adopt a position in support of speech rights. ${ }^{378}$ In the place of his earher comments about speech being simply "another act you don't like" came ones such as his 1925 remark to Laski that "I let out a page of slack on the right of an ass to drool about proletarian dictatorship.... Free speech means to inost people, you inay say anything that I don't think shocking."379

Perhaps the best evidence of Holmes' consciousness toward free speech issues in the last years of his tenure on the Court comes from his dissent in United States v. Schwimmer, ${ }^{380}$ written two inonths after his eighty-eighth birthday. The Schwimmer case concerned the application of a forty-nine-year-old woinan of Hungarian citizenship to becoine a citizen of the U1rited States. The woinan, Rosika Schwimmer, was a prouninent pacifist who, in 1915, wlien slee was still hiving in Hungary, liad persuaded Henry Ford to send a peace ship to Europe to, as she put it, "[bring] the boys out of the trenclies by Christmas." to the Umited States in 1921 to visit and lecture, and had subsequently become a resident of Illinois.

In November, 1921, slie declared lier intention to become a United States citizen and in Septeınber, 1926, filed a petition for naturalization. As part of the naturalization process, slee was given a "preliminary form" which required applicants to respond to various questions. Question 22 of the form asked whether an applicant for citizenship was " "willing to take up arms in defense of this country," "and Schwimmer answered in the negative. ${ }^{382}$

When Scliwimmer subsequently filed a petition for naturalization in the District Court of the Northern District of Illinois, leer petition was deined on the grounds tliat she was "unable ... to take the prescribed oatli of allegiance" and was, therefore, "not attached to the primciples of the Constitution of the United States" nor "well disposed to the good

377. 283 U.S. 697 (1931).

378. In Gilbert v. Minnesota, 254 U.S. 325 (1920), Holmes concurred in the result sustaining the conviction of an official of the Non-partisan League for giving a speech urging that the policy of conscripting soldiers in wartime be put to a popular vote. Id. at 333; id. at 334 (Holmes, J., concurring in the result). Holmes gave no reasons for his concurrence. It is possible that he thought that to do so would require the same substantive reading of liberty, in a preincorporation jurisprudence, that he had resisted in the foreign language cases. See text accompanying notes 34347.

379. Letter from Oliver Wendell Holnes to Harold J. Laski (June 14, 1925), in 1 HoLMESLASKI LETTERS, supra note 1, at 752 (footnote omitted).

380. 279 U.S. 644 (1929), overruled by Girouard v. United States, 328 U.S. 61 (1946).

381. See Rosika Schwimmer Dead at Age of 70, N.Y. TIMES, Aug. 4, 1948, at 21.

382. Schwimmer, 279 U.S. at 647. 
order and happiness of the same." 383 The Court.of Appeals for the Sixth Circuit reversed, finding that since Schwimmer was a woman and not eligible for military service, her refusal to bear arms was not any direct threat to the security of the nation. ${ }^{384}$ The Supreme Court granted certiorari and heard the case in April 1929.385

A inajority of the Court, through Justice Pierce Butler, reversed, concludimg that "[w] hatever tends to lessen the willingness of citizens to discharge their duty to bear arms detracts froin the strength and safety of the Government."386 Therefore, "opimions and behefs" as well as "behavior" were appropriate subjects of inquiry for the naturahzation authorities. ${ }^{387}$ Indeed, opimions and beliefs, in Butler's view, were "of vital importance, for if all or a large number of citizens oppose [the] defense [of tlie United States] the 'good order and happiness' of the Uinted States can not long endure."388

Holmes dissented, joined by Brandeis, and converted the case from a routine naturalization case into a free speech case. ${ }^{389}$ A portion of his opimion is worth quotimg at soine length:

The views referred to are an extreme opinion in favor of pacifisin and a statement that she would not bear arms to defend the Constitution. So far as the adequacy of her oath is concerned I hardly can see how it is affected by the statement, inasinuch as she is a woinan over fifty years of age, and would not be allowed to bear arms if she wanted to. .. . Surely it

383. Id. at 646 .

384. Schwimmer v. United States, 27 F.2d 742 (7th Cir. 1928), rev'd, 279 U.S. 644 (1929), overruled by Girouard v. United States, 328 U.S. 61 (1946).

385. Schwimmer, 279 U.S. at 644-45.

386. Id. at $650-51$.

387. Id. at 651 .

388. Id.

389. Id. at 653 (Holmes, J., dissenting). Technically Schwimmer was not conceptualized as a First Amendment case. Neither the majority nor Holmes mentioned the First Amendment. The majority pointed out that "aliens ... have no natural right to become citizens, but only that which is by statute conferred upon them" and that the burden was on applicants "to show by satisfactory evidence that [they have] the specified qualifications" for citizenship. 279 U.S. at 649.

The question in Schwimmer was therefore whether she had met the burden of establishing "the requisite facts" to make out a case for admission. The majority held that she had not met the burden because of her testiniony that she would not bear arms and that she was "an uncompromising pacifist with no sense of nationalism but only a cosmic sense of belonging to the human family." Id. at 651-52. "[O]pinions and beliefs as well as . . behavior," Butler pointed out, "are subjects of inquiry under the statutory provisions governing naturalization." Id. at 651. The process thus contemplated that First Amendment issues would not be raised if the government denied an applicant citizenship solely on the ground of his or her beliefs. Even though the Naturalization Act of 1906, ch. 3592, 34 Stat. 596, which established the naturalization procedures used in Schvimmer. would in effect be an example of "Congress . . . abridg[ing] the freedom of speech," U.S. CONST. amend. I, the First Amendment did not apply to aliens.

Holmes, in his dissent, spoke of the "principle of free thought" and called that a "principle of the Constitution." Schwimmer, 279 U.S. at 654-55 (Holmes, J., dissenting). He also cited the Schenck case, as if Schwimmer was doctrinally comparable. Id. at 654 . But he avoided mentioning the First Amendment. 
cannot show lack of attachment to the principles of the Constitution that she thinks it can be improved. I suppose that most intelligent people think that it might be. . . . To touch a more burning question, only a judge inad with partisanship would exclude [an apphcant for citizenship] because the applicant thought that the Eighteenth Amendment should be repealed.

Of course the fear is that if a war came the apphicant would exert activities such as were dealt with in Schenck $v$. United States. But that seems to ine unfounded. Her position and inotives are wholly different from those of Schenck. She is an optimist and states in strong and, I do not doubt, sincere words her behef that war will disappear and that the impending destiny of mankind is to unite im peaceful leagues. I do not share that optimisin nor do I think that a philosophic view of the world would regard war as absurd. But most people who have known it regard it with horror, as a last resort, and . . . would welcoine any practicable combination that would increase the power on the side of peace. . . . Solne of her answers might excite popular prejudice, but if there is any principle of the Constitution that more imperatively calls for attachment than any other it is the principle of free thought-not free thought for those who agree with us but freedom for the thought that we hate. I think that we should adhere to that principle with regard to adimission into, as well as to life withm this country. ${ }^{390}$

Before analyzing the free speech dimensions of Holmes' opinion, it is worth noting that the posture of the Schwimmer case arguably mooted any First Amendment arguments. Schwimmer had been asked a question about her willinguess to take up arms in defense of the country and had given an answer that would have been grounds for a summary denial of citizenship had the relevance of the question to a forty-nine-year-old woman meligible for military service not been at issue. The question in Schwimmer was not whether Congress was infringing on First Amendnent rights by asking the question and acting summarily if an applicant gave the "wrong" answer. No one was seriously questioning Congress' power to condition American citizenship on the avowal of certain behiefs; aliens seeking to be naturalized did not possess First Amendinent rights. Rather, the question was whether the United States could deny Schwimmer citizenship based solely on her disniclimation to perform an act she would not likely ever be asked to perform.

Holmes, however, analyzed Schwimmer's views as if the case concerned the First Amendnient. He stated that "[i]t is agreed that [Schwimmer] is qualified for citizenship except so far as the views" she had set forth, ${ }^{391}$ and then he proceeded to analyze those views as if the case were an ordinary First Amendnient case. He found it irrelevant that

390. Id. at 653-54 (citations omitted).

391. Id. at 653 . 
Schwimmer refused to bear arms because she was ineligible to do so anyway. He then trivialized her refusal to "defend the Constitution" as a mere belief that the Constitution can be improved-a belief that he suspected was shared by "most intelligent people."392 Holmes further suggested that Schwimmer's views on the Constitution and war were akin to the view that Prohibition should be repealed, and "only a judge mad with partisanship" would exclude an applicant who expressed the latter views. ${ }^{393}$

Holmes thus considered Schwimmer's views mild and inconsequential, like the leaflets he had described as "poor and puny anonymities" in Abrams v. United States. ${ }^{394}$ Having started down the line of First Amendment jurisprudence, Holmes now increased his rhetorical intensity. Schwimmer, he argued, might be thought a similar case to Schenck in that if war broke out Scliwimmer might commit acts like those Holmes had found pumshable in Schenck. He concluded, however, that Scliwimmer was in a different "position" and had different "motives" than Schenck. ${ }^{395}$ Schwimmer was a simcere pacifist; Schenck, by implication, a dangerous subversive. While Holmes himself did not share the optimism of pacifists, ${ }^{396}$ nor did he think that the idea of war was philosophically absurd, he, like "most people who liave known" war, regarded it witl "horror, as a last resort, . . . and would welcome any practical combination that would increase the power on the side of peace."397

After trivializing the dangerousness of Schwimmer's views, Holmes confronted the fact that some of her answers to questions about war and tlie obligations of citizenship "might excite popular prejudice."398 It was this very sort of answer, Holmes suggested, that was protected by the First Amendment. The "principle of free thought" was not only one "that more imperatively calls for attachment than any other" in the Constitution, it was desigued to ensure "freedom for the thought that we liate."399 That principle sliould extend not only to "life within this country" but to proceedmgs where people sought admission into the United States. ${ }^{400}$

In light of Holmes' earhier decisions as a Supreme Court Justice, this

392. Id. at $653-54$.

393. Id. at 654 .

394. 250 U.S. 616, 629 (1919) (Holmes, J., dissenting).

395. See Schwimmer, 279 U.S. at 654 (Holmes, J., dissenting).

396. Indeed Holmes had written Laski on April 13, 1929, before the Schwimmer case had been decided, that "[a]II "isms [including pacifism] seem to me silly-but this hyperaethereal respect for human life seems perhaps the silliest of all." Letter from Oliver Wendell Holines to Harold J. Laski (Apr. 13, 1929), in 2 Holmes-LASKI LeTTERS, supra note 1, at 1146.

397. Schwimmer, 279 U.S. at 654 (Holmes, J., dissenting).

398. Id.

399. Id. at 654-55.

400. Id. at 655 . 
language is rather extraordinary. First, it signified an apparent abandonment of the "clear and present danger" test. While Holmes continued to insist that Schenck was still good law and sought to distinguish it from Schwimmer on the basis of the defendant's "position and motives," he failed to use any "clear and present danger" language in Schwimmer. Instead, he suggested that the "principle of free thought," including "freedom for the thought that we hate," was now a more significant constitutional principle than any other. Moreover, the principle should apply to decisions affecting prospective citizens-aliens-as well as citizens; they should not be punished for expressing their views even if those views were "hateful" to most Americans.

Second, this language signified Holmes' abandonment of a positivist view of sovereignty. In the past, Holmes had been remarkably deferential to the power of the United States to treat ahens as devoid of constitutional rights. Indeed, he had been the principal early twentieth-century Supreme Court proponent of an ultrapositivist view of sovereignty and a starkly restrictiomist view of the rights of those who sought to enter or to reinam in the Umited States. ${ }^{401}$ In contrast, Holmes' opinion in Schwimmer suggested that the constitutional principle of free thought apphes to naturalization proceedings. In Schwimmer he was not only suggesting that a "principle of the Constitution" was iniplicated in a naturalization proceeding, he was suggesting that "the principle of free thought" was of greater constitutional significance than "any other."

Holmes' personal correspondence about the Schwimmer case further illustrates the extent to which Holmes' approach to free speech issues had become more hibertarian. By the time of the Schwimmer decision, Holmes' life was centered around his work and his correspondence, and he was writing freely to intiniates about his cases. In September 1928, he responded to a comment from Pollock criticizing "armchair pacifists" ${ }^{402}$ with sentinients strikingly similar to those found in his Schwimmer dissent. "I agree with your condenmation of arnchair pacifists," he wrote Pollock, "on the general ground that until the world has gotten farther along war not only is not absurd but is mevitable and rational." He added, however, that "I don't pass moral judgments." And in June 1929, $\mathrm{m}$ response to a letter from Laski declaring the majority opinion in Schwimmer to be "an iniquitous mjustice," 404 Holmes said

401. See generally Rogat, Dissenting Opinion (pt. 1), supra note 10 (discussing Holmes' restrictive alien-rights jurisprudence).

402. Letter from Sir Frederick Pollock to Oliver Wendell Holmes (Sept. 9, 1928), in 2 HolmesPOLLOCK LeTTERS, supra note 105, at 229.

403. Letter from Oliver Wendell Holmes to Sir Frederick and Lady Pollock (Sept. 20, 1928), in 2 HOLMES-POLlOCK LeTtERS, supra note 105, at 230.

404. Letter from Harold J. Laski to Oliver Wendell Holmes (June 4, 1929), in 2 HoLMES-LASKI LETTERS, supra note 1 , at 1155 . 
that he thought the opinion was affected by "a recollection of the antidraft talk during the late war" and was "made easier by [Schwimmer's] somewhat flamboyant declaration that she was an atheist," which he had "alluded to . . . discreetly without mentioning" in his dissent. ${ }^{405}$

In January 1930, Holmes received a letter from Rosika Schwimmer. She expressed her "deep-felt gratitude" for his dissent, even "[a]t the risk of violating legal etiquette." $406 \mathrm{He}$ responded, "You are too intelligent to need explanation of the saymg that you must never thank a judge."407 Holmes described a case as "simply a problem to be solved" and stated that if a judge's decision "was of a kind to deserve thanks, he would not be doing his duty."408 Nonetheless he confessed that he was "gratified by [Schwinmer's] more than kind expression,"409 and began a correspondence with Schwimmer that lasted until 1934, a year before his death.

It is not altogether surprising that Holmes, after admonishing Rosika Schwimmer for writing him, would then write her back and begin a correspondence friendship. She was thirty-six years younger than he, about the same age as Frankfurter, Laski, Chafee, and Learned Hand. Holmes had noted in his dissent that Schwimmer "seem[ed] to be . . . of superior character and intelligence."410 Though he thought her pacifism was naive, he did not hold the same view of her atheism. ${ }^{411} \mathrm{He}$ could have seen her as part of the constituency of his old age: the progressive intelligentsia that had come to appreciate him and might pass on his contributions to posterity. In his correspondence friendships with this circle of people, Holmes grew comfortable expressing his instinctive affinity for the commumicative arts, activities to which he had devoted his life. Just as he devoted an ever-increasing tine in his later life to reading and writing letters, he devoted more time to taking seriously "the principle of freedom of thought." Holmes' correspondence with Schwimmer is further evidence both of the evolution in Holmes' thinking about speech issues and of his contmued efforts to cultivate a constituency for his ideas.

405. Letter from Oliver Wendell Holmes to Harold J. Laski (June 15, 1929), in 2 HolmEsLASKI LETTERS, supra note 1, at 1158. Schwimmer's atheism may have been what Holmes was "allud[ingl to" when he said that "[s]ome of her answers might excite popular prejudice." United States v. Schwimmer, 279 U.S. 644, 654 (1929) (Holmes, J., dissenting), overruled by Girouard v. United States, 328 U.S. 61 (1946).

406. Letter from Rosika Schwimmer to Oliver Wendell Holmes (Jan. 28, 1930), in Holmes Papers, supra note 13.

407. Letter from Oliver Wendell Holmes to Rosika Schwimmer (Jan. 30, 1930), in Holmes

Papers, supra note 13.

408. Id.

409. Id.

410. Schwimmer, 279 U.S. at 653 (1929) (Holmes, J., dissenting).

411. Holmes had exhibited a skepticism about the existence of God by the age of 20. See 1 Howe, supra note 88, at 109-10; MARK DEWOLfE Howe, TOUChEd WITH FIRE: Civil WAR LETTERS AND DIARY OF OLIVER WENDELI HOLMES, JR. 1861-1864, at $27-28$ (1946). 
Holnies' opinions from Schenck through Schwimmer demonstrate that while the transformation of his ideas on free speech is readily discernible, the expression of that transformation in the form of consistent legal doctrime is not. Although on the surface Holmes appeared to continue to endorse the "clear and present danger" test as the best nieans for protecting speech rights, he made very little use of the "clear and present danger" test im his later opinions. He employed the formula as an analytical device only once in his later speech cases, in his dissent in Gitlow, and in the course of that dissent also appeared to endorse a variety of other tests for free speech cases in addition to "clear and present danger."

In other opinions written after Abrams Holmes imexplicably failed to apply the "clear and present danger" test at all. In Gilbert v. Minnesota, ${ }^{412}$ for example, decided just before Gitlow, it was liard to see how the advocacy of putting conscription to a popular vote could have resulted in a "clear and present danger" to the state under Holmes' Abrams reformulation. ${ }^{413}$ Under the "clear and present danger" test Gilbert's conviction for that advocacy seemed liarder to justify than Gitlow's, since Gitlow had explicitly called for class action liaving as its objective "the conquest by the proletariat of the power of the state." 414 Holmes nonetheless permitted Gilbert's conviction to stand, while insistnig that the "clear and present danger" test called for a reversal of Gitlow's conviction.

Even when Holmes went to great lengths to argue for the protection of speecl rights, as he did in his Schwimmer dissent, he did not apply his "clear and present danger" test. In Schwimmer, Holmes stated that one of the grounds for denying Scliwimmer citizenship was "the fear ... that if a war came the applicant would exert activities such as were dealt with in Schenck v. United States." ${ }^{415}$ But if by mentioning Schenck he meant to suggest that Schwimmer was a "clear and present danger" case, and that Rosa Scliwimmer's refusal to bear arms in the defense of the United States at some indefinite time in the future could hardly constitute a "clear and present danger," he did not nnake that suggestion clear. He only said that Scliwimmer's "position" and "motives" were "wholly different" froin those of the defendant in Schenck and then went on to dis-

412. 254 U.S. 325 (1920).

413. The defendant in Gilbert also said that "[i]f they conscripted wealth like they have conscripted men, this war -would not last over forty-eight hours." Id. at 327.

414. Gitlow v. New York, 268 U.S. 652, $658 \mathrm{n} .2$ (1925). It is possible, of course, that Holmes declined to protect the speech in Gilbert because of the necessity of relying on a "liberty of speech" argument. See supra notes 64-86 and accompanying text. But on its facts, the Gilbert case hardly represented a "clear and present danger" as Holmes had come to define one after Abrams.

415. United States v. Schwimmer, 279 U.S. 644, 654 (1929) (Holmes, J., dissenting), overruled by Girouard v. United States, 328 U.S. 61 (1946). 
cuss the "optimistic" and "sincere" quality of Schwimmer's pacifism. ${ }^{416}$

It would, of course, have been hazardous for Holmes to state openly that the "clear and present danger" standard actually governed in Schwimmer or that the First Amendment was even relevant to the case. Holmes did say, however, that the "principle of free thought" should pertain to "admission mto, as well as to life within this country."417 In that context his citation of Schenck, and his effort to distinguish the defendants in Schwimmer and in Schenck, seems doctrinally curious. It is not clear whether he was suggesting that in the future the "clear and present danger" test he had outlined in Abrams should be applied to naturalization proceedimgs or simply that Schenck, Abrams, and Schwimmer were all cases in which the principle of "protection for the thought we hate" was imphicated. In sum, all that one can conclude from a close analysis of Holmes' later free speech opinions is that he was regularly conscious of the free speech iniphications of cases and persistently solicitous of free speech claims. Even that conclusion needs to take into account Gilbert and the foreign language cases, in which he exhibited no solicitude for the free speech claim or no consciousness that there even was one. As for the "clear and present danger" test as a doctrinal formulation, Holmes imght have wanted to give the impression that he continued to adhere to it, but he very rarely used it and in many instances did not even mention it.

$\mathrm{V}$

\section{CONCLUSION: Holmes' SENSIBILITY AS A JUDGE}

This exercise in exploring Holınes' free speech opinions has yielded several conclusions. First, Holmes' consciousness about the free speech dimensions of cases in 1929 was hight-years away from that in the 1890s, when he decided the McAuliffe and Davis cases, or that in 1915, when he decided Fox v. Washington, or even that in the spring of 1919, when Schenck and the other Espionage Act cases were decided. By the time he was deciding the Gitlow and Schwimmer cases, Holmes' consciousness had shifted from that of a judge for whom speech issues seemed incidental, or trivial, or inerely subsumed in other common-law issues, to one for whom speech issues were of central constitutional iniportance.

This Article has argued that the shift in Holmes' consciousness is best explained by Holmes' personal experiences and relationships. Events in his personal life and his own unfulfilled career expectations made him more receptive to the ideas of Laski, Frankfurter, Hand, and Chafee and the circle of commentators who wrote in The New Republic during and immediately after World War I. The interest of these intel-

416. Id.

417. See id. 
lectuals in reframing free speech jurisprudence easily dovetailed with Holmes' interest in disassociating free speech from the jurisprudential underpinnings of "liberty of contract." When one undertakes a close coinparison of Holmes' language in his Schenck and Abrams opinions, and places those opinions in the context of his intellectual friendships at the time, it is apparent that Holmes' exchange of views with younger intellectuals influenced him to abandon the analogy between the free speecli cases and criminal-attenipt cases and to reconfigure free speech jurisprudence as enranatimg from the premise of the social interest in free speech in a deniocracy. This reconfiguration led him, by the Schwimmer decision, to the affirmation of the principle of "freedom for the tliouglit we hate."

While it might be tenipting to conclude that early twentieth-century First Amendment doctrine mirrors this evolution in Holmes' thouglit and, therefore, that the reformulated "clear and present danger" test articulated in Abrams is the beginning of modern First Amendment analysis, ${ }^{418}$ suclı a conclusion would be incorrect. First, Holmes' general free speech fornulations in his opinions were not logically consistent. Holmes had atteinpted two general justifications for the protection of free speech: his statement in Abrams that the "theory of our Constitution" was that "the best test of truth is the power of the tliouglit to get itself accepted in the competition of the inarket"419 and his statement in Schwimmer that "if there is any principle of the Constitution that inore iniperatively calls for attachment than any other it is the principle of free thought-not free thought for those who agree witl us but freedom for the tliought that we hate."420 He never clarified, lowever, how "the thouglit that we hate" could have any "power to get itself accepted in the conpetition of the market" and, therefore, how "the theory of our Constitution" could be squared witl the constitutional principle of freedom for hated thoughts.

Second, although Holmes had said in Schenck that the "clear and present danger" test was to determine the himits of protection for speecli "in every case," ${ }^{21}$ he failed to apply that test consistently after Schenck. In Abrams he had refornulated the test, and in some later cases, sucli as Schwimmer, he went beyond the test he had articulated in Abrams. In

418. See, e.g., Harry Kalven, JR., A Worthy Tradition: Freedom of Speech IN AMERICA (1988) (discussing evolution of free speech doctrine in the United States); MURPHY, FREEDOM OF SPEECH, supra note 72 (focusing on the development and application of the First Amendinent during the 1920s); Melville B. Nimmer, Nimmer on Freedom of Speech (1984) (describing First Amendment doctrine in the twentieth century and exploring themes underlying the protection of speech).

419. Abrams v. United States, 250 U.S. 616, 630 (1919) (Holmes, J., dissenting).

420. United States v. Schwimmer, 279 U.S. 644, 654 (1929) (Holmes, J., dissenting), overruled by Girouard v. United States, 328 U.S. 61 (1946).

421. Schenck v. United States, 249 U.S. 47,52 (1919). 
other cases, such as Gilbert, he failed to invoke the test or even to recognize the free speech issues at all. Holmes' failure to apply the "clear and present danger" test consistently is evidence that perhaps he did not intend it as a doctrinal guidehine at all. His reformulation of the test in Abrams might simply have been an atteinpt to create an appearance of consistency between his dissent in Abrams and the earlier version of the test that he had formulated in Schenck.

One thus coines to see that Holmes' free speech opinions were not ineant to serve as conventional doctrinal formulations, providing guidance for the consistent interpretation of constitutional provisions. They were meant to serve as vehicles for conveying Holmes' broader philosophical views to the world, vehicles by which Holmes implicitly sought to change the frame of reference within which free speech issues were viewed, to inodernize First Amendment theory. In 1911 Holmes wrote a letter to Lewis Einstein in which he described the state of mind from which he approached his work as a judge:

The point that I have in view is continually to deepen and broaden the channels for the great forces that he behind every detail. After a man has a working knowledge of his job it is less important to read the late decisions of other Courts, which generally are but the small change of thought, than to let in as much knowledge as one can of what ultimately determines those decisions; philosophy, sociology, economics, and the like. I am not an expert in those matters; but I open as inany windows on them as I can, and fondly hope that in some way the habit of trying to see the particular in the hight of the universal will tell in one's writing. ${ }^{422}$

The passage shows Holmes' iniphicit sense of priorities as he wrote opimions. Reading "the late decisions of other Courts," the "small change of thought," was afforded a low priority because those decisions typically did not reveal "the [philosophical, sociological, and economic] great forces" that "ultiniately determined" the course of judicial decisionmaking. Holmes' method of revealing the existence of those "great forces" was to try "to see the particular in the hight of the universal" and accordingly, to express particular details of cases in hight of those "universal[s]" rather than in hight of the "late decisions of other Courts." "The thing I have wanted to do" as a judge, Holmes wrote to Canon Patrick Sheehan in recognizimg the tenth anniversary of his tenure on the Supreine Court, has been "to put as many new ideas into the law as I can, to show how particular solutions involve general theory, and to do it with style." 423

Holmes expressed his consciousness in free speech cases in a way

422. Letter from Oliver Wendell Holmes to Lewis Einstein (June 24, 1911), in HoLMESEinstein Letters 59 (James B. Peabody ed., 1964).

423. Letter from Oliver Wendell Holmes to Canon Patrick A. Sheehan (Dec. 15, 1912), in Holmes-SHEEHAN CORRESPONDENCE, supra note 107, at 56. 
consistent with the priorities he expressed to Einstein and Sheehan. When he first became attracted to the "new idea" that speech meant more than protection froin prior restraints, he sought to express the limits of that protection in his Schenck dictum, placing the facts of Schenck in the universal language of "clear and present danger"-language that seemed at that tinne to capture for him the close connection between subversive speech and crime. As he rethought speech issues after Schenck in response to criticism he had received from people whose opinions he valued, he sought to "open as many windows" as he could on the philosophical basis of protection for speech. One window that appeared promising was the reformulated basis of protection for speech as part of the "search for truth" in a democratic society that valued public discussion, and Holmes again sought to express that basis as a universal proposition embedded in the particular facts of Abrams.

The idea of the search for truth, however, did not fully justify the protection of speech rights. Though the search for truth was to take place in a competitive marketplace, that marketplace, in a deinocracy, was not completely free because it was controlled by majoritarian preferences. Thus, "getting accepted" meant, in soine sense, "being popular"; if truth was to be equated with popularity a majority inight choose to treat unpopular speech as untrue and suppress it. That was the problem in Gitlow and, in an abstract fashion, in Schwimmer. In both cases, representatives of a majority had deemed communism or pacifism unacceptable doctrines. Holmes responded by trying yet another umiversal formnlation: the idea that the "only meaning of free speech" was that unacceptable doctrines be presumptively tolerated; that the Constitution embodied the principle of freedom for the thought that we hate.

This process of modernizing free speech theory reveals Holmes' distimctive sensibility as a judge and his ambivalence about the professional role he occupied. Though Holmes had hittle interest in the orthodox dimensions of his own profession's work product-the "small change of thought" manifested by "the late decisions of other Courts"-he wanted to be recognized, and celebrated, as a judge. Holmes often treated judging as a kind of game, an exercise in which he tried to find "a form of words" to justify a result, as he would try to find fresh and arresting language to express a thought in a letter. At the same time, however, the game was a serious one for Holmes, because he was also greatly interested im having his talents widely appreciated in the form of an exalted judicial reputation. In the sentence following his comment on domg his work with "style" in the 1912 letter to Sheehan, he had written, "I should like to be admitted to be the greatest jurist in the world." 424

When one looks over the progression of Holmes' free speech juris- 
prudence, one despairs of finding a coherent theoretical pattern or of squaring his stance with positivist premises or with conventional theories of judicial deference to the will of the majority. At times Holınes seemed to exhibit a minimalist conception of speech, as "another act" inajorities may not "like"; at other times he seemed to inflate protection for speech to the most important and imperative of constitutional principles. His philosophical conception of speech evolved through stages that at first blush seem principally the products of his intuitive responses and his personal and professional goals. The implications of his stance toward First Amendment issues double back on many of his other jurisprudential positions. Liberty of contract, for example, was a dangerous illusion, an invitation to judicial overreaching, yet the protection for the principle of "freedoin for the thought that we hate" was at the core of the Constitution. When one examines Holmes' free speech opinions froin the perspectives of doctrine and theory, one finds inconsistencies and contradictions at every turn.

When one thinks, however, of those opimions as the products of a writer whose principal concern is to open "windows" on a philosophical issue, to see "the particular in the light of the universal," the opinions take on a different meaning. They appear less as doctrinal than as inetaphorical statements. Their purpose is not to achieve logical consistency but to offer "form[s] of words" that convey the universal diniensions of free speech theory. Whatever the limitations of "clear and present danger," "the search for truth," and "freedoin for the thought that we hate" as analytical guides, they are vivid encapsulations of concerns and values that recur in speech cases: reminders that Holmes the writer has glimpsed the universal in the particular. In his free speech opinions Holmes the writer arguably did precisely what he told Canon Sheehan he wanted to do: to put new ideas into the law, to show how particular "solutions" to legal issues involved general theory, and to communicate with style.

Holmes the writer, however, was also Holmes the judge. Holnies the judge made decisions that affected people's lives, sought to square his opimions with his previous judicial pronouncements, and operated within the confines of existing doctrine. In his free speech opinions, as in his judicial work as a whole, Holines the writer was regularly in tension with Holmes the judge. That tension was soinetines acute for Holmes, because while he sought to achieve the goals of a philosopher-jurist for whom writing was the ineans of cominunicating his insights, he also sought esteen as a judge. Since he assuined that doctrinal consistency and theoretical integrity were prerequisites for esteen in a judge, he sought to use forms of words to create the appearance of consistency and integrity in his opinions. His own instinct for glimpsing the universal in 
the particular betrayed him in that search. Having invented a doctrinal formula in one free speech case, he saw its himitations in another and sought one more all-encompassing.

The result was that Holmes became associated with the modernization of free speech theory in a fashion that was consistent with his goals as a jurist but inconsistent with the conventional professional expectations for a "contributing" judge. Holmes' intellectual journey through free speech cases introduced four conceptions of speech in early twentieth-century American history. The first was speech as "another act we don't like," personified by the "criminal attempts" analogy; the second, speech as "the search for truth," personified by the reconfigured "clear and present danger" test; the third, speech as the vehicle by which "the dominant forces of the community" exercised their power; the fourth, speech as "the primciple of freedom for the thought that we hate." Each conception further complicated and refined the philosophical dilemma of protection for free speech in a modern constitutional democracy. Each conception carried with it a logically inadequate doctrinal formula for resolving speech issues. The cumulative inadequacy of the formulas served to demonstrate the complexity of the philosophical dilemma.

Holmes thus appears, in this history of his free speech opinions, as a resonant intelleetual figure, a "hightning rod" for cultural and ideological messages in the first thirty years of the twentieth century. His resonance emerges from his roles as a jurist-philosopher, refiecting upon the imtellectual conflicts of his tine, and as a writer, communicating his refiections in vivid and memorable forms of words. It emerges less clearly, almost imcidentally, in his role as a judge. With Holmes' free speech opinions, as with his judicial work as a whole, a purported exercise in doctrinal analysis becomes one in which the language of doctrine quickly disintegrates, revealing other language-language communicating the hunian, intellectual, and cultural dimensions of Holmes' opinionsbeneath the surface. When one explores this language one coines to recognize the sources of Holmes' emmence. 
